\title{
Sundials on the Quirinal: Astronomy and the Early Modern Garden
}

\author{
Denis Ribouillault
}

\begin{abstract}
This paper deals with the function and meaning of sundials in Early Modern Rome, more specifically in gardens. It concentrates on two gardens, both on the Quirinal hill and directly facing each other: the papal gardens of Monte Cavallo and the Jesuit garden of the Noviciate of Sant'Andrea del Quirinale. Set on each side of the magnificent Via Pia, these gardens represented two intersecting yet contrasting worlds, a rude juxtaposition of one cosmos clashing against another: that of a Jesuit community and that of the Papal court. Each had developed a specific language to articulate their main concerns and proclaim their truths to garden visitors. By drawing a contrasting picture of the S. Andrea garden and the Papal gardens, in which sundials were given very different meanings, the intent of this paper is to probe the awkward, contradiction-ridden, spinoso relationship between religion, science and curiosity in Early Modern Rome.
\end{abstract}

In 1685, the Dutch civil engineer Cornelis Meyer devised a method to re-erect the obelisk of Augustus, which had formed part of a famous ancient sundial known as the Horologium Augusti. Published in a book on hydraulic engineering, Meyer's method was supplemented by an entire section in which he explained how one could transform Rome's piazze, with their obelisks and columns, into colossal sundials. He suggested that the obelisk be erected on Piazza Monte Cavallo on the Quirinal hill and that the monument be given back its ancient gnomonic function (Fig. 1). Meyer's elaborate gnomon would determine the hours of the night through the use of the same type of pierced gnomon that would be used a century later, in 1792, when the obelisk was finally erected on Piazza

\footnotetext{
D. Ribouillault $(\bowtie)$

Département d'histoire de l'art et d'études cinématographiques, Université de Montréal, Pavillon Lionel-Groulx, 3150, rue Jean-Brillant, Montréal, QC, Canada H3T 1N8

e-mail: denis.ribouillault@umontreal.ca
} 


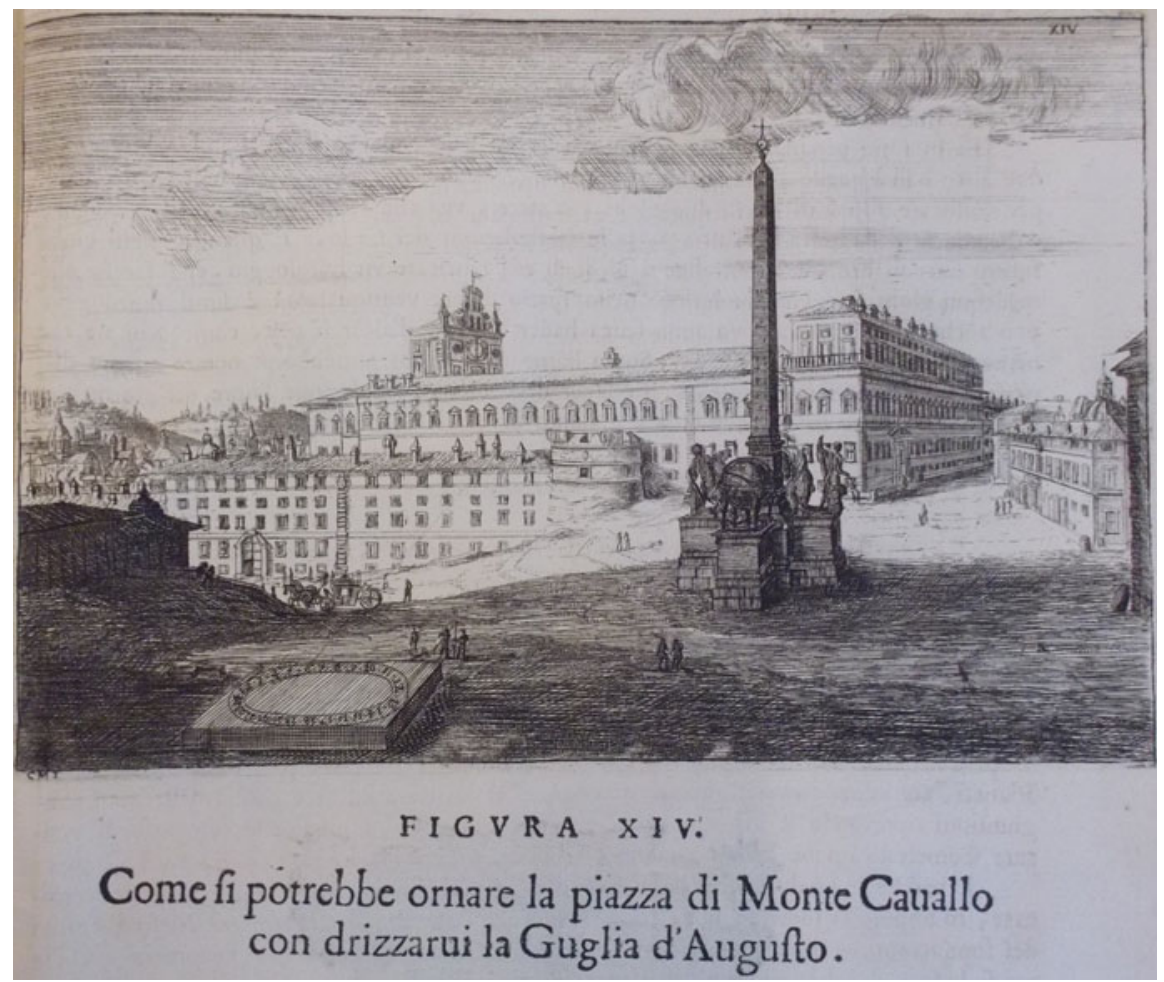

Fig. 1 Gaspar van Wittel (?), Project for the Piazza Montecavallo, in Cornelis Meyer, Arte di restituire a Roma la tralasciata navigazione del Tevere, Rome, 1685, pl. XIV

Montecitorio. ${ }^{1}$ The obelisk could also be completed, Meyer suggested (1685: pl. XIV), with enormous revolving terrestrial and celestial globes:

One would represent all Kingdoms and Provinces of the Earth, and the other the constellations of the Heavens. And were these globes to be made of bronze, one could build at their foot a clock, which would make those same globes wheel completely around during the space of twenty-four hours, and similar clocks can be made, without the necessity of using weights, such as one we possess which comes from Holland. On those

\footnotetext{
${ }^{1}$ This article is a development of a portion of the paper I presented at the conference Gardening and Knowledge. Landscape Design and the Sciences in the Early Modern Period, entitled "Measuring Time in the Gardens of Papal Rome" (Hannover, 17-19 September 2012), which is currently being developed as a book with the provisional title Gardens of the Heavens. Astronomy and the Science of Time in the Gardens of Papal Rome. I owe a lot to Volker R. Remmert for his constant encouragement in the preparation of this article, Joseph Connors for his generous reading and enlightening suggestions and Mandy MacDonald for revising the English and editing my translations.
}

On the history of this obelisk, see Pliny (1940: XXXVI, 70-73), D'Onofrio (1967: 280-291), and Iversen (1968: 142-160). 
same globes there could be noted again various curious observations, either to know from their revolution the hours of the day and of the night, as also, what time it is at a given hour in any part of the world. ${ }^{2}$

Meyer is still little known to art historians today, yet his book is a strong reminder that astronomy and gnonomics - the term 'dialing' is still used by English specialists-were fundamental fields of study in Rome, and on the Quirinal hill especially, and had been for more than a century. ${ }^{3}$ Although in his chapter on sundials, Meyer leaves aside the complex mathematics of the dials, his imaginary description of Rome, transformed into one immense astronomical observatory, is proof that the science of the heavens had a deep impact on the way architectural and urban space were perceived in seventeenth-century Rome.

This paper deals with the function and meaning of sundials in Early Modern Rome, more specifically in gardens. One might imagine that the subject had already been explored, given the long tradition of studies dedicated to Roman gardens in the Renaissance and Baroque periods. Compared to the numerous studies devoted to fountains and statues, however, the presence of clocks, sundials and other such astronomical or mathematical instruments has been surprisingly overlooked by scholars, perhaps because evidence for such ornaments in Rome is scarce compared to that for Northern European gardens, where they are plentiful. David Coffin (1991: 184), in his otherwise comprehensive book on the gardens of Papal Rome, gives only two examples of garden sundials. ${ }^{4}$ Since I started researching this topic, I have come to realize that this does not reflect historical reality. Several Roman gardens from the sixteenth to the eighteenth centuries featured sundials prominently. Their presence is significant to an understanding of their function, their cultural meaning and what has traditionally been called their "iconography". Moreover, they strongly suggest that astronomical debates had an important impact

\footnotetext{
${ }^{2}$ Meyer (1685: pl. XIV) and corresponding chapter: "Si legge appresso Plinio, che Augusto haveva trovato un modo di dimostrare mediante l'ombra di essa Guglia l'hore della notte, Divus Augustus (dic'egli) addidit mirabilem usum ad deprehendendas dierum, noctiumque magnitudines, digna cognita res: onde mi venne desio d'insinuare, che volendo far servire la medesima Guglia al primevo suo uso, si potrebbe lasciare nella sommità sotto la Croce un apertura à Foggia d'un piccolo Cerchio per il quale traguardando la stella detta Tramontana potrebbesi formare sopra il piano opposto ad essa Guglia un horologgio da sapere l'hore notturne... [...] et in oltre per maggior ornamento della medesima piazza potrebbonsi aggiungere due altre basi à quelle, che vi sono di presente (come si dimostra nel sudetto disegno) per collocare sopra di questi due globi, ò sfere, una che rappresentasse tutti li Regni, e Provincie della terra, e l'altra tutte le Costellationi del Cielo. E quando questi globi fussero fatti di bronzo si potrebbe à piedi di essi fabricare un horologio, che facesse alli medesimi globi fare una rivolutione nello spatio d'hore ventiquattro: e simil horologgio può anche farsi, che vada un anno senza haver bisogno d'alzar li pesi, come Noi ne tenemo uno fatto venire d'Olanda. Sopra li medesimi globi potrebbonsi notare ancora diverse altre osservationi curiose, sì per saper della di loro rivolutione l'hore del giorno, e della notte, come anche, che hora è appunto in quell'istesso tempo in qualsivoglia parte del Mondo".

${ }^{3}$ Further on Meyer, see Van Berkel (2002), Fagiolo (2014) and Connors (2015).

${ }^{4}$ Conversely, Coffin devotes an entire chapter to the subject in his book on English gardens. See Coffin (1994: Chap. I). This is not the place to give an extensive bibliography on the links between astronomy and the Church, but a classic work to seek out is Heilbron (1999).
} 
on the world of the garden in early modern Rome. How astronomical knowledge was appropriated and transformed by this specific context and what this neglected dimension tells us about the world of gardens are among the questions that will be raised. To do this, I will concentrate on only two gardens, both on the Quirinal hill and directly facing each other: the papal gardens of Monte Cavallo and the Jesuit gardens of the Noviciate of Sant'Andrea del Quirinale. Set on each side of the magnificent Via Pia, these gardens represented two intersecting yet contrasting worlds, a rude juxtaposition of one cosmos clashing against another: that of a Jesuit community and that of the Papal court. Each had developed a specific language to articulate their main concerns and proclaim their truths to garden visitors. By drawing a contrasting picture of the S. Andrea garden and the Papal gardens, in which sundials were given very different meanings, the intent of this paper is to probe the awkward, contradiction-ridden, spinoso relationship between religion, science and curiosity in Early Modern Rome.

\section{Astronomy and the Quirinal Gardens from Gregory XIII to Urban VIII}

The garden at Monte Cavallo had already acquired a strong astronomical dimension during the pontificate of Gregory XIII at the end of the sixteenth century, possibly linked with the presence on the hill of an ancient temple of the Sun. ${ }^{5}$ In 1584 , a Tower of the Winds was built there to echo the more famous one at the Vatican, linked with the calendar reform and fitted with an elaborate meridiana and an anemoscope by the mathematician Egnazio Danti. ${ }^{6}$ To my knowledge, no known document demonstrates explicitly that this tower possessed a gnomonic function like that of its twin sister at the Vatican. Yet the fact that it was given the same name as its Vatican counterpart reveals Gregory's will to establish a link between the two monuments, reinforcing his claim to power over the Roman landscape and the cosmos at large. ${ }^{7}$ Evidence that such a meaning was well established is provided by a poem by Principio Fabricii, published in 1588 in an emblem book in which astronomical themes are central. The accompanying emblem shows the villa of Monte Cavallo and its tower as the new centre of the pope's power over the entire world (Fig. 2).

Con ampii giri la superba Mole

Ch'l Regno importa ben fondato, e retto

Cinge Drago immortal, Signor perfetto,

Che i Soggetti ugualmente intender vuole.

E quale in mezo à i celesti Orbi il Sole

\footnotetext{
${ }^{5}$ On the Quirinal palace and its gardens, see Coffin (1991), Fagiolo (1998), Frommel (1999/2002) and Zampa (2007).

${ }^{6}$ On the Quirinal Tower of the Winds, see Tesi (1991: 90) and Courtright (2003: 177-181).

${ }^{7}$ For instance, Giovanni Baglione, in his Life of Martino Longhi, speaks of the tower as the "Torre dei venti": see Baglione (1642: 68). For a discussion of the Vatican-Quirinal axis at the time of Gregory XIII, see Meadows-Rogers (1996: 205-221).
} 


\section{PRINCEPS. LIB. VI. TIT. I. ALLVS. VIII.}

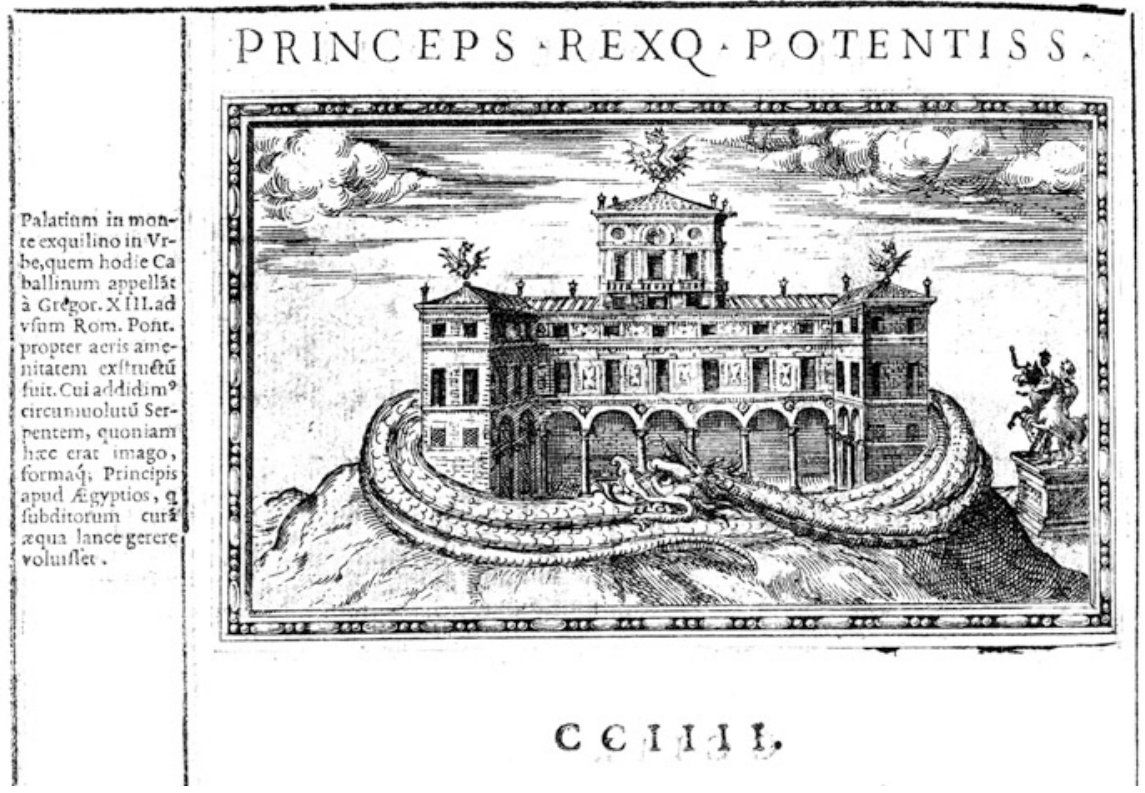

Fig. 2 Villa Montecavallo encircled by the Boncompagni Ouroboros dragon in Principio Fabricii, Delle allusioni, imprese, et emblemi..., Rome, 1588, 308, Bibliotheca Hertziana, Rome

Alluma, e scalda con sereno aspetto

Come à Saturno, à la Sorella il petto,

Tal Qvesti à ogn' Alma, che l'honora, e cole.

Del Mondo Italia è un piccol Mondo, e Roma

E d'ambi il Capo, ove riluce, e splende

Con nova Sfera il Pastor santo, e giusto.

Tal che non men può venerar sua chioma,

Che del foco divin gli Animi accende,

Il Gelato German, che l'Indo adusto. (Fabricii 1588: 308$)^{8}$

In the engraving, the Quirinal tower is topped by an impressively large Boncompagni dragon with open wings, while another large snake-like dragon biting its own tail as in the hieroglyphic ouroboros, encircles the whole building, a symbol of cyclicality and eternal return. This kind of symbolism was definitely

\footnotetext{
8 "In wide circles the immortal dragon, symbolizing equally the perfect master and his subjects, winds itself around the proud and huge edifice, which is of concern to the well — and rightlyestablished kingdom. And just as the sun shines in the midst of the celestial bodies and warms the breast with [its] serene countenance, as from Saturn to the Sister, so to each one of these, who honors her, is she the nourishing hill. Italy is a little world within the world, and Rome is the head of both, where the holy and just Pastor shines and sparkles with a new orb. So that no less can frigid German than the parched Indian venerate his Head, who kindles souls with divine fire." MeadowsRogers (1996: 360-361). On the work of Fabricii, see Ruffini (2005) and Aksamija (2011).
} 

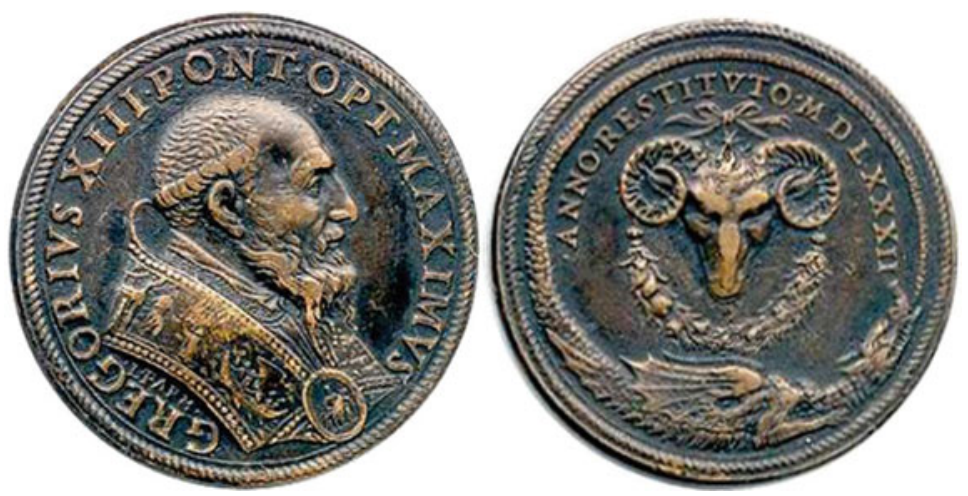

Fig. 3 Medal of 1582 celebrating the calendar reform. Recto: portrait of Gregory XIII; verso: Aries (standing for the vernal equinox) with the Boncompagni dragon shaped like the Ouroboros with the inscription ANNO RESTITVTO MDLXXXII, (C) Wikimedia Commons. Image is in public domain

associated with the Gregorian calendar reform in a medal of 1582 (Fig. 3). The mechanical clock on the tower is generally considered to have been added later at the time of Urban VIII, but some evidence points to the presence of such a clock already being there in Gregory's time. On the church of Sant'Atanasio dei Greci, on today's Via del Babuino, there is a beautiful clock whose pointer is very interestingly shaped like the ouroboros dragon (Fig. 4). ${ }^{9}$ In a passage from the Memorie de Capitoli del Collegio dei Greci for the year 1677, one can read that the clock's pointer came- "according to hearsay, not documents"-from the palace of Monte Cavallo. ${ }^{10}$ Although no other document exists to prove this, it shows none the less that, even a century later, the Quirinal was still associated in people's minds with Gregory's reform and his poetics of time and astronomy.

The villa's connection with astronomy was made even stronger during the pontificate of Pope Urban VIII, when a monumental sundial or meridiana tetracycla was installed in the garden in conjunction with two armillary spheres visible in the engraving of the garden made by Giovan Battista Falda: one on the top of a small pavilion, or padiglione di verzura, and another very large one set on a balustrade immediately above the Fontana dell'Organo (Fountain of the Organ) (Fig. 5a, b, c). Regarding the localisation of the sundial within the garden, Filippo Camerota and Marcello Fagiolo relied, in their respective articles on the subject, on a document dated November 2, 1628 specifying that the sundial was set "nel mezzo del Giardino novo di Monte Cavallo". Fagiolo suggested a precise spot for this placement, at the

\footnotetext{
${ }^{9}$ Although the dragon-shaped pointer of this clock refers to the Pope's coat of arms, it is worth recalling the use of the dragon on contemporary astronomical clocks to indicate lunar nodes and determine solar and lunar eclipses.

${ }^{10}$ The two campanili of the church are described thus: "Uno per uso delle campane che sono due e di buon suono e l'altro per l'orologio il quale, come corre tradizione ma nelle scritture non si truova notato, era quello che stava nel palazzo di Monte Cavallo che la S. ${ }^{\text {tà }}$ N. Di Gregorio XIII comprò da Signori di Casa d'Este". See Angelucci (1991, 1993).
} 

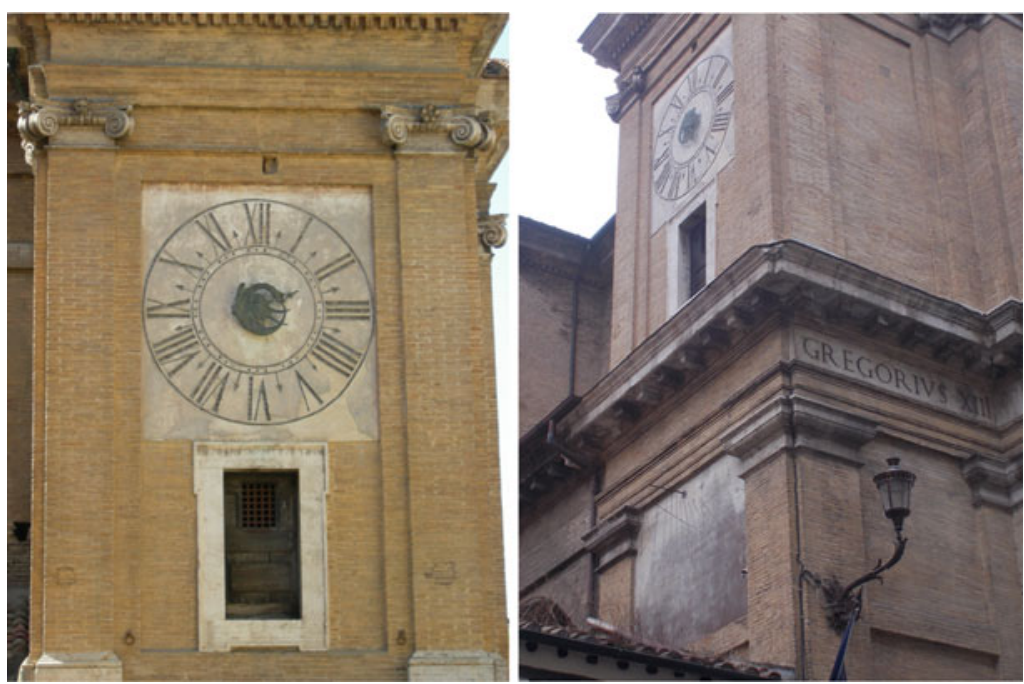

Fig. 4 (a-b) Mechanical clock of Sant'Atanasio dei Greci with the pointers shaped like the Boncompagni Ouroboros dragon, Rome. (a) (C) Wikimedia Commons. Image is in public domain. (b) Photo author

crossing of the two main axes of the garden. Although this location is consonant with other projects conducted by Carlo Maderno in this area of the garden, the sundial was either never placed there or was rapidly removed, since Giovan Battista Falda depicted it elsewhere in his second engraving of the garden, dated circa 1680: in that work, it is clearly visible next to the aviary (uccelliera, corresponding to the ex-Casino dei Grimani) marked 20 on the plan (Fig. 6a, b). This location, close to a view from which one could admire the stupendous panorama of Rome, is consistent with the ways in which sundials were placed in contemporary Roman gardens. The sundial drawn by Falda is topped by the Pope's tiara and keys ("Un Regno con doi chiavi [...] che fa finimento sopra per adornamento di detto Horologio") and set on a large square pedestal and not the column with ancient capitals described in the 1628 document mentioned above. ${ }^{11}$ In his Horarium universale perpetuum, published in 1637, the mathematician Teodosio Rossi explains that he himself suggested to the pope the idea of building a sundial for his garden in 1624, during the ceremonial benediction of the three bells of the new campanile that marked the hours on the Tower of the Winds, or torre dell' orologio. The sundial would serve to correct the cumulative error of the mechanical clock, which up to the middle of the

\footnotetext{
${ }^{11}$ On the Quirinal sundial, see Camerota (2000). The document of 2 November 1628, "Misura e stima de lavori diversi fatti per servitio di N.S. in far l'Horologio à Sole Posto nel mezzo del Giardino novo di Monte Cavallo, e fatti da m.ri Agostino Radi e Francesco Castelli, compagni scarpellini," is in Archivio di Stato di Roma, Camerale I, Giustificazioni di Tesoreria, b. 62, fasc. 7, ins. 1. For an hypothesis regarding the original placement of the sundial, see Fagiolo (2000). Here I repeat only the essential information given in these two important studies, to which I refer for further information and bibliography.
} 

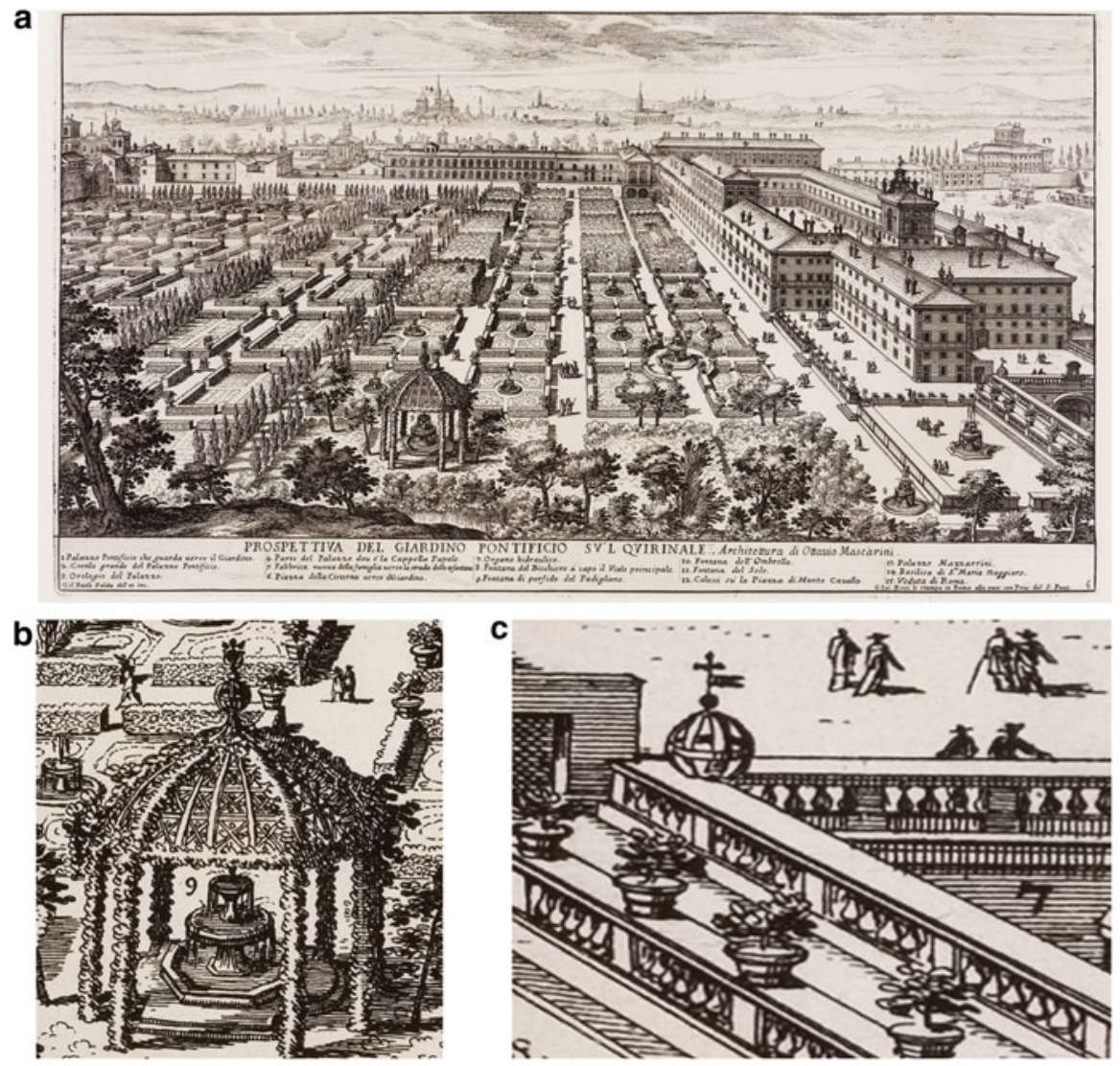

Fig. 5 (a) Prospettiva del giardino pontificio sul Quirinale, in Giovan Battista Falda, Li giardini di Roma. .., Roma, s.a., Canadian Center for Architecture, Montréal. (b) Detail of the armillary sphere on top of the Padiglione di verzura. (c) Detail of the armillary sphere above the Fontana dell'Organo

seventeenth century was of the order of 15 min per day. The sundial, one of the first Roman works of the famous architect Francesco Borromini, was constructed in 1628 in collaboration with Agostino Radi. Rossi, a student of Christoph Clavius, was considered to be one of the finest experts on gnomonics in Rome. His gnomonic tables, compiled and published in 1593 to guide the construction of sundials for the latitude of Rome, were put to use for the design of the Quirinal sundial.

The sundial is described and illustrated in Athanasius Kircher's treatise on sundials, Ars magna lucis et umbrae, published in 1646 (Kircher 1646: 359-360). Originally, it had four gilded bronze gnomons indicating the hours, wrought in the form of the Barberini family's emblems, three bees and a sun. At present, however, the only original elements of the sundial that survive are the four-sided marble drum and the foot supporting it. The imagery was completed with two inscriptions. One, along the upper border of the sundial's foot, suggests an emblematic image of the pope guided on earth by heavenly light, SUPERNI LUMINIS DUCTU. The other, at the base of the foot, is taken from Virgil's Georgics and describes bees as "custodians 

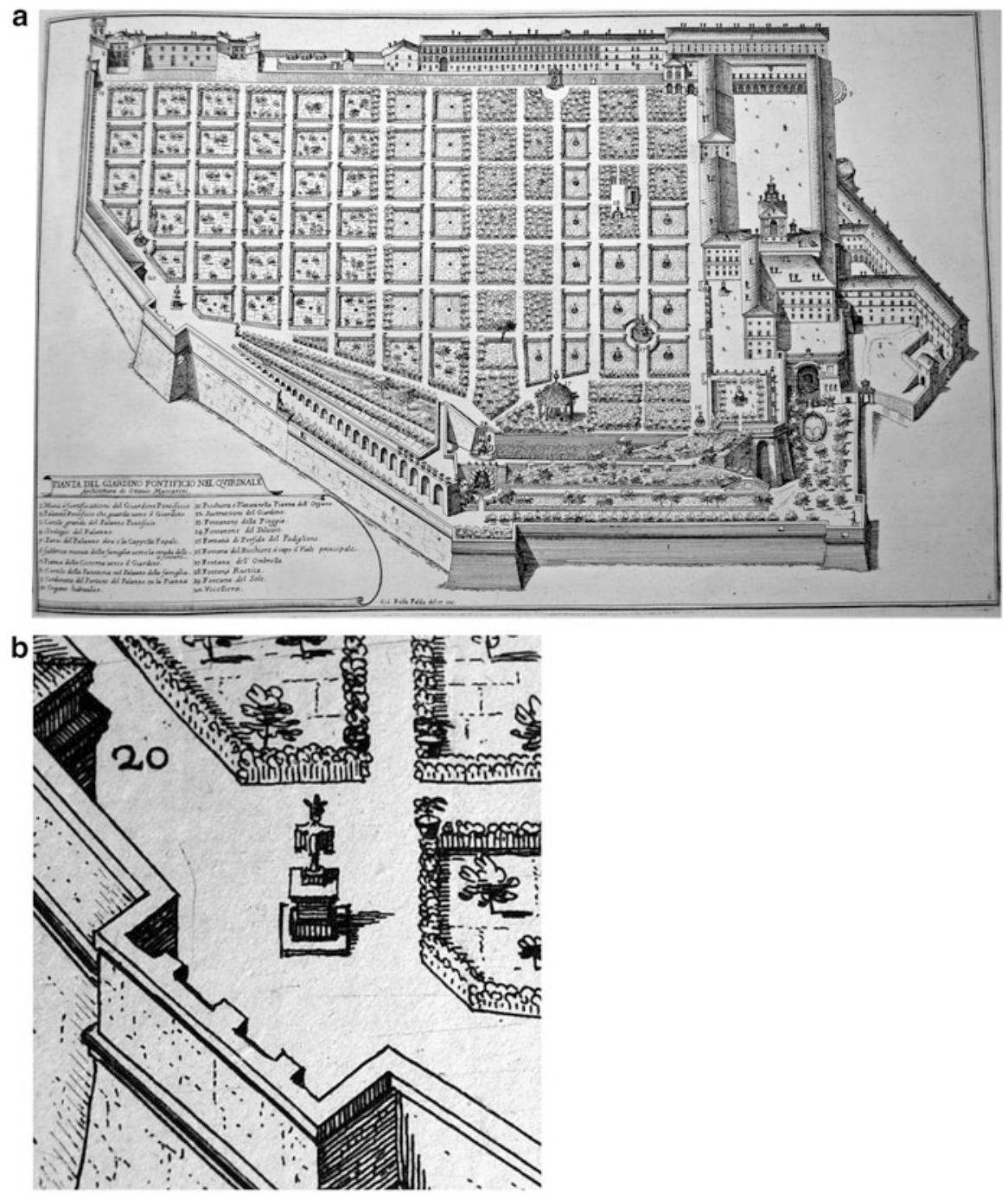

Fig. 6 (a) Pianta del giardino pontificio nel Quirinale, in Giovan Battista Falda, Li giardini di Roma. . ., Roma, s.a., Canadian Center for Architecture, Montréal. (b) Detail of the Tetracycle sundial

of the doors and observers of the heavens" (Virgil, Georgics: IV, 164-165: "Sunt quibus ad portas cecidit custodia sorti...") (Figs. 7 and 8).

The link between the sundial and the pope's heraldic emblems is logical and very appropriate. The association between gnomon-from an etymological and philosophical point of view, the sundial or gnomon designates that which understands, decides, judges or distinguishes (Serres 1986) — and nomen, meaning "name", originally gnomen and thus deriving from the same root (gno) meaning "know", is semantically highly charged, and implies a meaningful confusion 

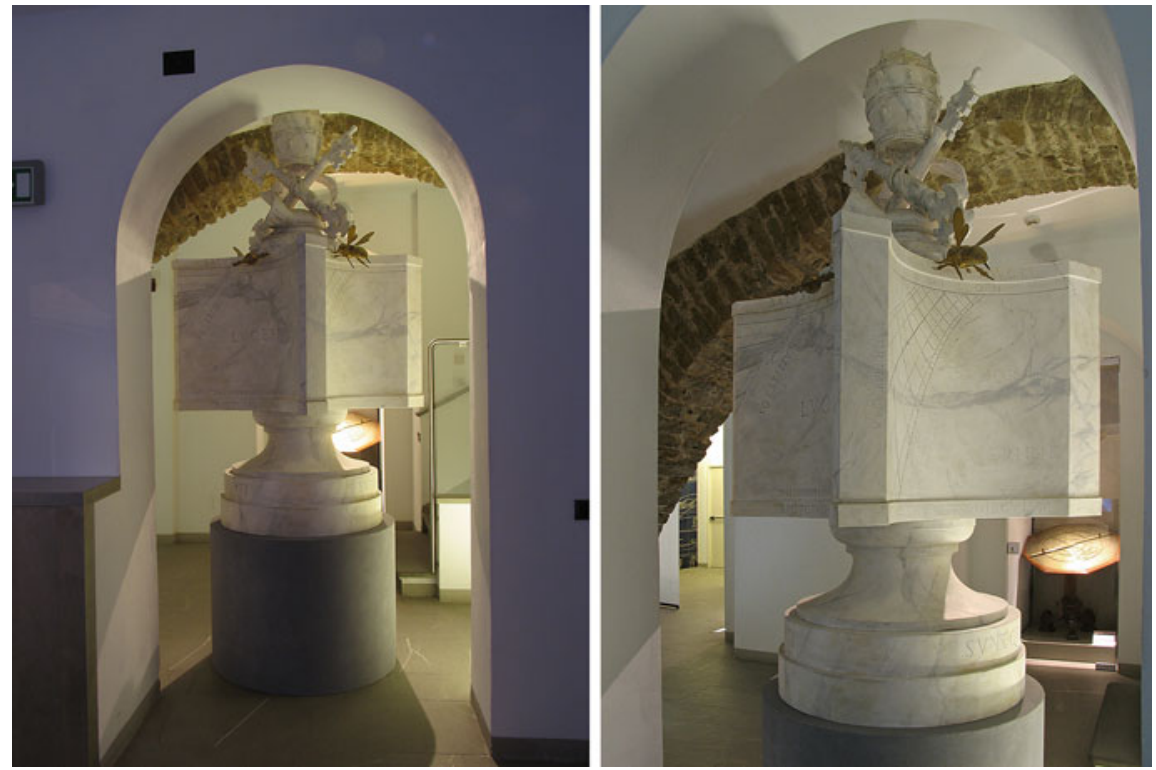

Fig. 7 (a-b) Francesco Borromini and Agostino Radi, 'Tetracycle' sundial, marble and bronze, 1628, (formerly in the Gardens of the Quirinal Palace, Rome), modern reconstruction, Museo Galileo, Florence

between identity and cosmology. The rising sun was one of the most widely diffused emblems of the new Pope. It is visible, for instance, in Giovan Ferro's Teatro d'imprese, published in 1623 and dedicated to Cardinal Francesco Barberini, in which many sundials are also used as emblems. Claude Lorrain's beautiful landscapes with a rising sun made for Urban VIII may have been the highest artistic expression of this imagery (Beaven 2007).

Bees were also directly related to astronomy. It was believed in antiquity that honey came not from flowers but from the heavens. This view was still held in the Renaissance, when it was thought that honey descended from the sky in the morning dew and was dispersed over the earth, drying in the warmth of the sun to a sweet white powder, which the bees collected and made into honey. This commonplace was repeated, for instance, by Torquato Tasso in a dialogue on Imprese of 1594, in which he states: "Bees make honeycombs from flowers, the wax from the tears of trees and the honey from the dew of the air, mostly in the birth of the stars and the vault of heaven". ${ }^{12}$ So the sundial's imagery was especially appropriate in the context of a garden.

12 “. . . l'api facciano i favi de' fiori, la cera de la lacrima de gli alberi, il mele de la rugiada de l'aria il più de le volte nel nascimento de le stelle e de l'arco celeste"; cited in Quiviger (2003: 317-321). The most detailed description of the celestial origin of honey appears in Pliny (1940: XI, xii, $30-32)$. 


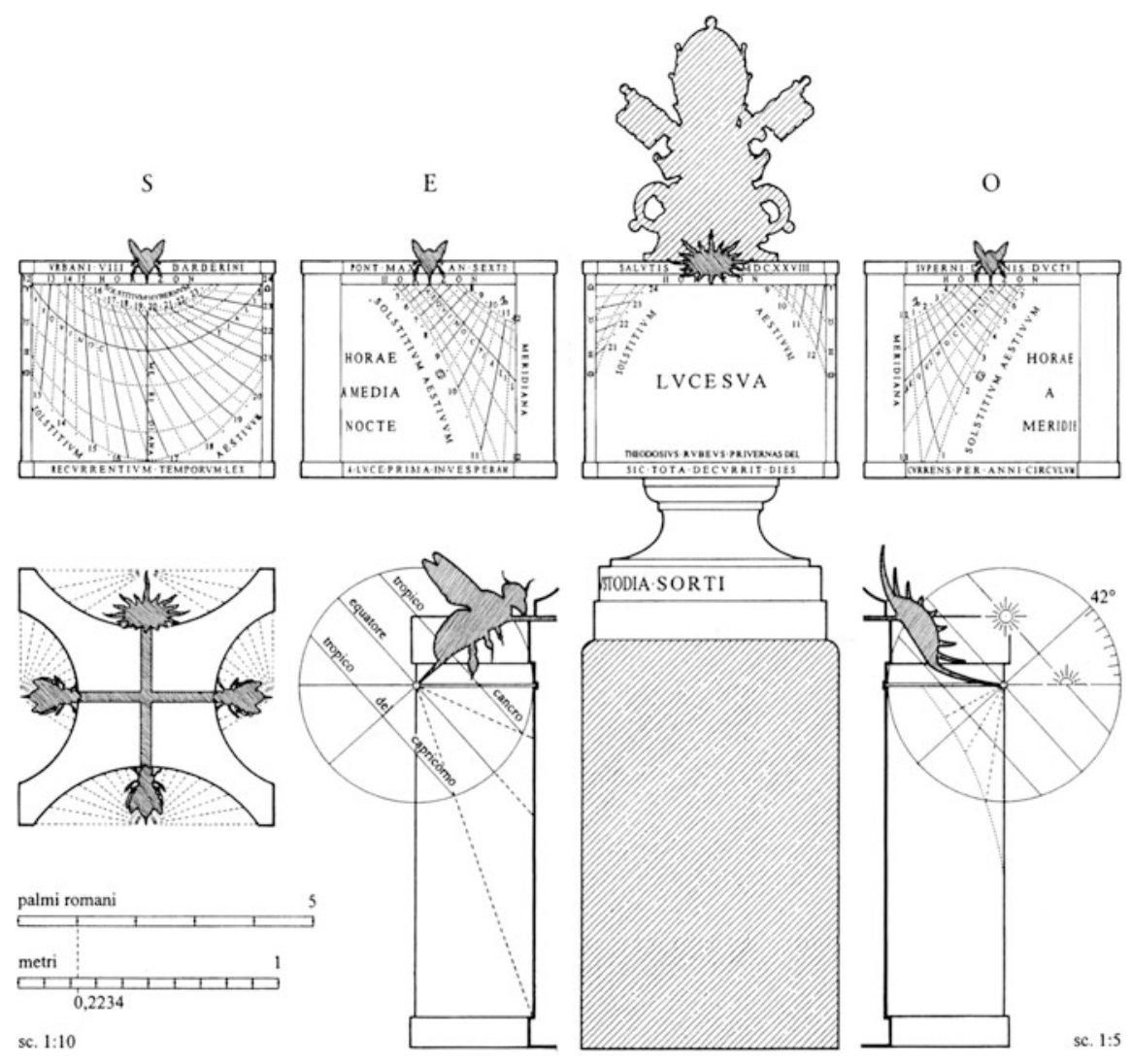

Fig. 8 Reconstruction of the Tetracycle sundial by F. Camerota (2000)

\section{Galileo in the Gardens of Baroque Rome}

Urban VIII's decision to strengthen the astronomical dimension of the Quirinal gardens is undoubtedly related to his recognition of the original link between the Quirinal tower and Gregory XIII's reform of the calendar. The fact that he had both the gallery of maps and the Vatican tower restored proves that he fully endorsed Gregory's attention towards astronomy and cosmology. ${ }^{13}$ Yet the link between astronomy and the Quirinal gardens had never ceased to be strong. Indeed, Galileo himself presented his latest discoveries on sunspots in the Quirinal garden, as he recalls in a letter to Antonio Antonini dated February 20, 1638: "nel tempo che io mi trovavo in Roma, dove più volte le feci vedere a molti prelati grandi negli Orti Quirinali". The information is confirmed by Angelo De Filiis in his Istoria e dimostrazione intorno alle macchie Solari e loro accidenti di Galileo (1613)

${ }^{13}$ For the restoration of the Vatican tower by Urban VIII, see Mancinelli and Casanovas (1980: 12). 
and again by Vincenzo Viviani, who, in his biography of the scientist, gives the date of the demonstration as April 1611. ${ }^{14}$ Another of Galileo's demonstrations took place in the garden of Cardinal Ottaviano Bandini, very close to the Quirinal papal gardens. ${ }^{15}$ These observations were made with the aid of an instrument that would be later termed a helioscope, whereby the image of the sun was projected through a telescope onto a sheet of white paper on which it was then easy to record the different spots observed. The instrument is described by Galileo's great rival at the time, the Jesuit Christoph Scheiner (1630: 137-138).

If the Quirinal gardens were a stage for Galileo's success, they were also to be the site of his downfall: from 1615 to 1633 , most meetings of the Congregazione del Santo Uffizio, which conducted his trial, took place at the Quirinal palace (Galluzzi 2009). Certainly many other astronomical experiments took place in gardens, which, together with high towers, were the logical place for them to be conducted. The armillary sphere set in the Quirinal gardens, visible in the engravings by Giovan Battista Falda, was also probably used for such a purpose, as this instrument was particularly useful for teaching the concepts of astronomy. Its location at a point offering a magnificent and unimpeded view over the entire city of Rome is proof that the instrument must have been used for practical demonstrations (Fig. 5c). However, situated below the Tower of the Winds and above the marvellous hydraulic organ of the Fontana dell'Organo, later restored by Athanasius Kircher (Barbieri 1981), ${ }^{16}$ it almost certainly also played an important symbolic role, linking the space of the gardens with the heavenly spheres. Here, astronomy, hydraulics and music, sciences which were all derived from mathematics, performed together for the edification and pleasure of the visitor. It is well known that, during his visit to Rome in 1611, Galileo displayed his instruments in various places, often in the setting of an evening meal and to the accompaniment of music. This was most probably the case with the famous outdoor banquet organized by Federico Cesi on April 14 of that year, in the gardens of Monsignor Malvasia on the Janiculum hill, where Galileo showed his new telescope to a group of eminent scientists (Shea and Artigas 2003: 33). In a letter to his friend Filippo Salviati, Galileo enthusiastically recalls his visits to Roman gardens: "I have been received and fêted by many illustrious cardinals, prelates and princes who wanted to see the things I have observed and were much pleased, as I was too, on my part, in viewing the marvels of their statuary, paintings, frescoed rooms, palaces, gardens, and so on" (Shea and Artigas 2003: 39).

\section{The Sundials of the Jesuit Garden of Sant'Andrea del Quirinale}

Before further investigating the possible significance of the Barberini sundial, we may pursue this brief overview of the Quirinal gardens' astronomical dimension by mentioning the presence of two sundials in the nearby Jesuit garden of Sant'Andrea

\footnotetext{
${ }^{14}$ Galileo (1890-1909: XVII, 297; V, 81-82; and XIX, 612). See Galluzzi (2009).

${ }^{15}$ Galileo (1890-1909: XII, 175).

${ }^{16}$ The Organ was made in 1596 by Luca Blasi. The hydraulic organ is described and illustrated in Kircher (1650: t.2, 343, Iconismus XXI).
} 
del Quirinale. They are described quite precisely by the Jesuit father Louis Richeome in La peinture spirituelle, published in Lyons in 1611, and can be seen on a print showing the garden attributed to Matthias Greuter inserted into the book (Fig. 9). The description is worth citing at length:

I have finished what I had to say about the pictures of this first garden. As you are leaving, I advise you to look at two noble pieces by the great Christopher Clavius, the Euclid and Archimedes of our century, and great ornament of the celestial sciences in our Company. One is the horizontal clock drawn on slate, planted on the pillar in the corner of the second square [indicated by the letter $\mathrm{E}$ in the view of the garden], and the other [is the] vertical [sundial] on the façade of the house [indicated by the letter C]; both of the old invention, not of Anaximenes of Miletus, who was a disciple of Thales, one of the seven sages of Greece, and lived in the year 3560, but of the Egyptians and Hebrews, who used them long ago, namely in the year 3356, more than two hundred years [earlier], as [appears] from the history of the Kings, where it is said that the prophet Isaiah, who lived in that time, gave a sign of the truth of his prophecy by making the shadow of the royal sundial move back by ten lines, which was a great miracle, even greater than that of Joshua who only stopped the [course of the] sun [...]. Now, these two dials are the same picture and serve the same purpose with their shadows; [they] mark the course of the sun, the days and hours in every possible way, the astronomical, Babylonian, Italic, French, ancient and modern hours. They warn you in all these ways that time passes unceasingly and rolls at extreme speed without returning, although the sun keeps returning every day and every year. They tell you when twenty-four hours are completed, when the day is over and is no more. These [periods of] twenty-four hours end at different times, depending on the variety of clocks and the limitations of the natural day consisting of its twenty-four members and parts. In Babylon, Judaea and [in] Eastern countries, where they count the beginning of the day at sunrise, they end at daybreak. On the contrary, in Italy, now as formerly in Athens, they end at sunset, because their day is from one sunset to the next. Depending on the astronomers' dials, they end at noon, for their day is done at noon. On the contrary, in ancient Rome and for the ancient Egyptians, they end at midnight, [...], a practice still used by the Roman Church and in all Christendom and for the feast days and mysterious days, because they start and end at midnight (Richeome 1611: 499-502). ${ }^{17}$

\footnotetext{
${ }^{17}$ I have transcribed the original text in modern French in the passages from Richeome quoted here, changing the punctuation to facilitate reading.

TABLEAU TROISIÈME DES IARDINS. LES HORLOGES, OU QUADRANS. J'ai achevé ce que j'avais à dire des tableaux de ce premier jardin. Je vous avertis en sortant de regarder deux nobles pièces du grand Christophe Clavius, l'Euclide et l'Archimède de nos siècles, et grand ornement des sciences célestes en cette compagnie. L'une est l'horloge horizontale, tracée sur cette ardoise, plantée sur le pilier en l'angle de ce second carré [indicated by the letter $\mathrm{D}$ in the view of the garden]; Et cet autre vertical, aligné en la muraille du logis [indicated by the letter $\mathrm{C}$ ], tous deux de l'invention ancienne, non d'Anaximène Milésien, qui fut disciple de Thalès, l'un des sept sages de Grèce, et vécut l'an du monde 3560, mais des Égyptiens et Hébreux, qui, longtemps auparavant, à savoir l'an 3356, plus de deux cents ans [auparavant], en avaient l'usage, comme il [ressort de] l'histoire des Rois, où il est dit, que le Prophète Isaïe, qui vivait en ce temps-là, donna un signe de la vérité de sa Prophétie, [en] faisant rétrograder l'ombre du cadran Royal de dix lignes, [ce] qui fut un grand miracle: voire plus [grand encore] que celui de Josué qui arrêta seulement le Soleil [...]. Or, ces deux cadrans sont un même tableau et un même office par leurs ombres, et [...] marquent le cours du Soleil, les jours et les heures en toutes façons; à l'astronomique, à la Babylonienne, à l'Italique, à la Française, à l'antique, et à la moderne. Ils vous avertissent en toutes ces manières, que sans pause le temps coule, et roule d'une extrême vitesse sans revenir, encore que le Soleil revienne, et
} 


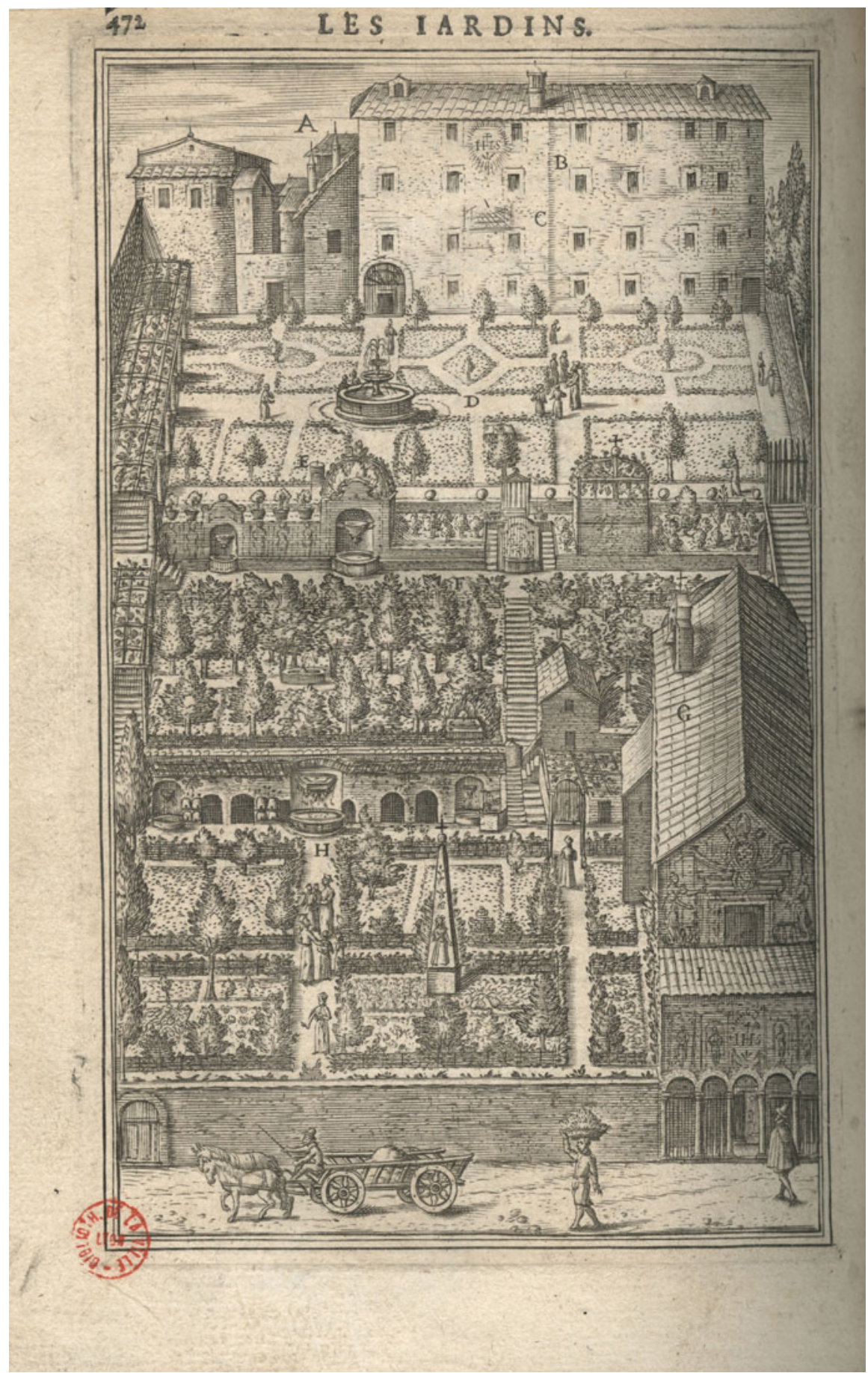

Fig. 9 Attributed to Matthias Greuter, The Garden of the Jesuit Noviciate of Sant'Andrea al Quirinale, Rome, in Louis Richeome, Peinture spirituelle..., Richeome (1611: 64), (C) Bibliothèque Municipale de Lyon 
Richeome's description of the sundials is typical of his book, which is both a meticulous description of the garden, the house, the church and their decoration and an allegorical reading of the world, a sort of exegetical promenade. ${ }^{18}$ The sundial maker, the Jesuit Christoph Clavius, was by far the most renowned astronomer of his time and his Gnomonices libri octo, published in Rome in 1581, was considered the ultimate work on the subject of gnomonics. It was written during the very years when Clavius was working on the calendar reform, which was established in 1582. ${ }^{19}$ The garden sundials were extremely elaborate, especially as they indicated the time in many different places, in keeping with the Jesuits' presence all around the world. This geographical dimension echoed that given to the scenes of martyrdom painted by Tarquinio Ligustri in 1599 in the nave of the church of San Vitale, which was an integral part of a visit to the Noviciate complex. ${ }^{20}$ The choice and arrangement of the plants and trees in the garden of Sant'Andrea were also deliberately symbolic, reflecting martyrological subjects. ${ }^{21}$ Pilgrims and students would have immediately made the connections between these different parts of the garden or were likely to be reminded of them by their Jesuit guides. An illustration of the interrelation between the Jesuits' geographical and astronomical pursuits would later be given by the indefatigable Jesuit scientist Athanasius Kircher, who depicts a universal sundial in his Ars magna lucis et umbrae of 1646 (Fig. 10). ${ }^{22}$ It is in the shape of an olive tree rooted in Rome, whose branches extend to locations

reprenne ses tours, et retours journaliers, et annuels. Ils vous disent, que quand vingt quatre heures sont accomplies, le jour est fini, et n'est plus. Ces vingt quatre heures finissent en divers temps, selon la diversité des horloges, et limites du jour naturel composé de ces vingt quatre membres et parcelles. En Babylone, en Judée, et [dans les] pays orientaux, où l'on compte le commencement du jour au lever du Soleil, elles finissent à la pointe du Jour. Au contraire, en Italie, maintenant, comme jadis en Athènes, [elles finissent] au Soleil couchant, parce que leur jour est d'un couchant à l'autre. Selon les cadrans des Astronomes, elles finissent à midi, car leur jour se fait en midi. Au contraire, selon l'ancienne Rome et les vieux Égyptiens, elles se terminent à la minuit, [...], ils marquaient les points de leurs jours, [une] façon qui se garde encore en l'Église romaine, et par toute la Chrétienté et [pour les] fêtes, et [les] jours mystérieux, car on les commence et les finit à la minuit.

${ }^{18}$ For a brief but useful description of the Quirinal garden and Richeome's description of it in English, see Witte (2011: 102-108). See also Davidson (2006). On Richeome, see Fabre (1995), Guiderdoni-Bruslé (2001), Van Assche (1999), Gijsbers (1999), Bailey (2003a: 48-52), Bailey (2003b: 129-137), Höltgen (2004), Dekoninck (2005: 68-75, 78-81, and 119-121), and Loach (2012).

${ }^{19}$ Clavius'most important works regarding sundials and the calendar reform are Gnomonices libri octo, Rome, 1581; Fabrica et usus instrumenti ad horologiorum descriptionem peropportuni, Rome 1586; Astrolabium, Rome, 1593; Horologium nova descriptio, Rome, 1599 and Romani calendarii a Gregorio XIII restituti explicatio, Rome, 1603. Further on Clavius, see Lattis (1994: 67-91).

${ }^{20}$ On Ligustri's martyr cycle at San Vitale and its link with Jesuit geography, see Bailey (2003a: 166-186); on the Noviciate of Sant'Andrea, (ibid.: Chap. 2: 38-106). On Jesuit geography, see Harris (1999).

${ }^{21}$ Macioce (1990: 122-123), Macioce (1995), Van Assche (1999), and Bailey (2003a: 167).

${ }^{22}$ On this print, see Godwin (1979: 78-79) and Harris (1999: 219). 


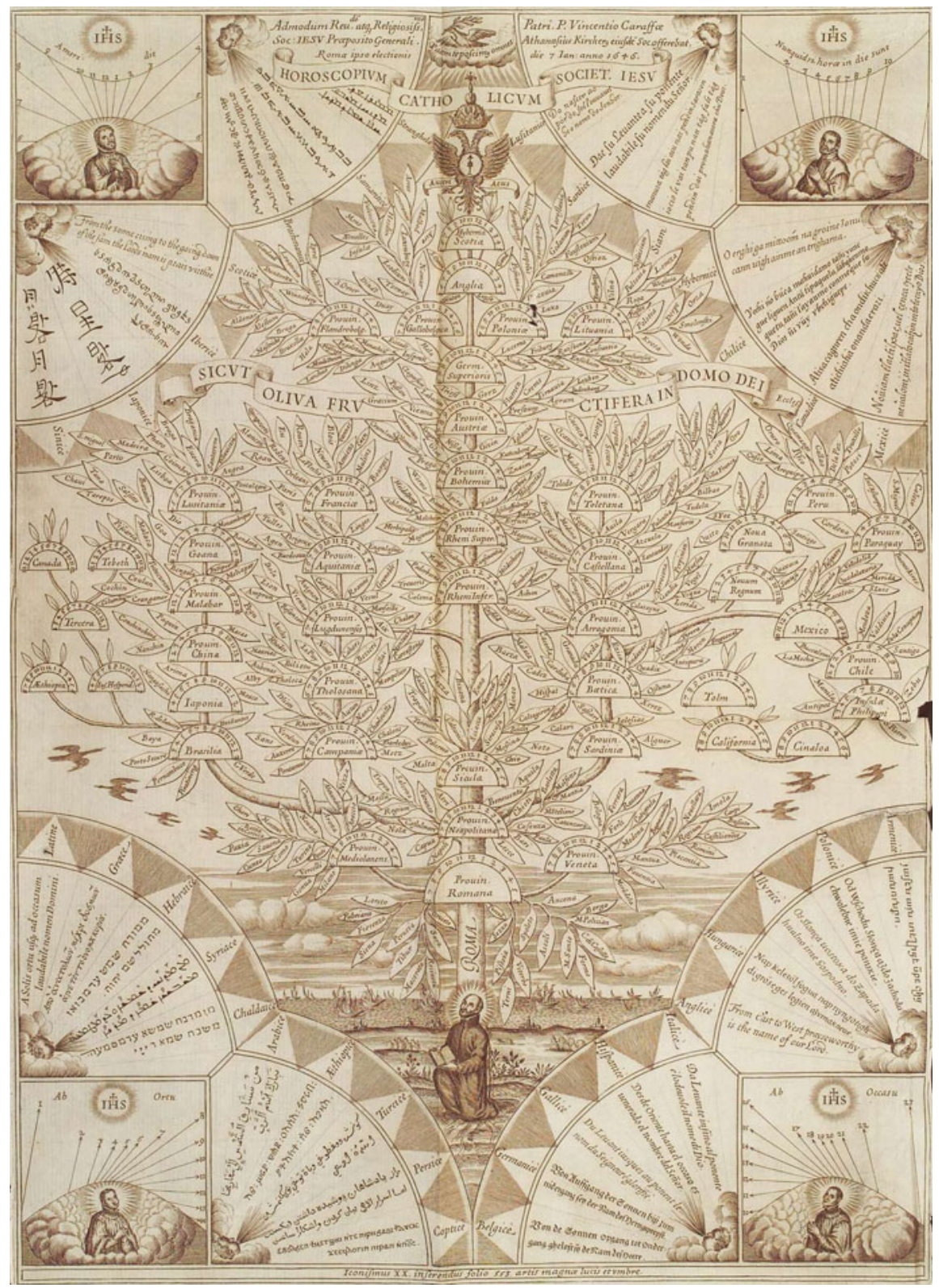

Fig. 10 Universal dial, in Athanasius Kircher, Ars magna lucis et umbrae, Rome, 1646, fol. 553 (Iconismus XX), (C) from Remmert $(2011,75)$

around the world; each "olive" on the branch contains a miniature sundial set for the specific latitude. Surrounding the tree, the eight winds, corresponding to the different directions and parts of the world, are blowing not air but words in the respective language for each region. At the four corners, Jesuit saints are seen praying below four vertical sundials related to the cardinal directions and comparable to the quadrant visible on the garden façade of the Noviciate in Greuter's image 
(Fig. 9). Richeome also underscores the universality of the Christian message at the end of the book in his enthusiastic description of the Jesuits' pastoral activities, which recalls the Pentecostal moment (Acts 2:4-11) when all those on whom the Holy Spirit has descended understand each other, though speaking in many languages: "You will see Italians, Germans, Poles, Bohemians, Hungarians, Flemings, Walloons, Irish, Scots, Englishmen, Greeks, Spaniards, Frenchmen, and other nations of Christianity, and all are taught in their mother tongue, and each of you has your separate group and your school in the same place, and without confusion." Let the message of San Vitale, he concludes, reach "not only you, but also everyone who dresses like you, in other similar houses placed on the five parts of the habitable world" (Richeome 1611; Bailey 2003a: 186).

As in Rome, sundials were given a very prominent place within Jesuit houses all around the world. Another extraordinary example of the use of sundials for the purpose of demonstrating the universality of the Jesuit mission is the elaborate universal sundial of the Jesuit Collège de la Trinité of Villeroy near Lyons in France, where astronomy was taught to novices as early as 1604. Dated 1662, it gave the time in the 37 colleges of the Company, and was part of an elaborate pictorial programme celebrating the college as a Temple of Wisdom. ${ }^{23}$ Also worth mentioning within the framework of this study is the famous pyramidical sundial built in 1669 by Jesuit Father Francis Line, also known as Francis Hall, for Charles II of England's garden at Whitehall (Line 1673; Coffin 1994). Line's sundial boasted the traditional royal symbols, as well as portraits of the king, queen and other members of the nobility. It is an interesting example to compare with Borromini's Quirinal sundial, not only for its use of heraldic symbols reinforcing social and political power, but also for its links with knowledge, mathematics and curiosity. Because this elaborate sundial was especially useful for demonstrating astronomical theories, Line was even requested by a friend of Galileo to have a similar dial sent to Rome to help defend the theory of heliocentrism. Before that, Line had devised several other sundials which caught the attention of European literati. Some of those served as ornaments in the garden of the Collegii Anglici societatis Jesu Leodii, the English Jesuit College in Liège, with Father Line using them to teach the principles of astronomy and mathematics. They were described in his Tractatus de horologiis (University of Liège, Ms. 377; Sauvenier-Goffin 1958). ${ }^{24}$

But let us return to Sant'Andrea. Some of Richeome's remarks about the placement of the sundials in the garden are particularly interesting. For him, the two sundials are to be considered together ("ces deux cadrans sont un même tableau, et un même office"), although they are not placed near each other. Likewise, in the papal garden we have just left, the various astronomical instruments created a web of interconnected objects, which could be linked thematically by the moving visitors. For instance, the astronomical ornaments entered into

\footnotetext{
${ }^{23}$ For a full description, see Menestrier (1663: 101ff) (Description et explication des montres solaires tracées dans les trois faces de la grande cour du Collège de la Trinité). For an analysis of the cultural context, see Van Damme (2005).

${ }^{24}$ On Father Line, see further Reilly $(1962,1969)$.
} 
dialogue with some of the fountains in the garden, such as the Fountain of Apollo and the Fountain of the Sun (numbered 11 on Falda's view), both with explicit solar imagery (Fig. 6a). In the Jesuit garden, the two sundials not only resonated with San Vitale's martyr cycle, as mentioned above, but were also echoed by the presence of an obelisk located on the lower square of the garden (Fig. 9). Supplied with imprese and inscriptions directly pertaining to astronomy, the sun and the winds, this obelisk possessed a complex moral and exegetic significance, which Richeome explains in great detail in his book (Richeome 1611: 667-671): for instance, the eastern face shows the figure of Christ and the sun and the words, "His name is Orient" (Zechariah 6:12-13), thus recalling the very symbol of the Jesuit order that is also depicted on the vertical sundial.

\section{Sundials and Astronomical Debates in Baroque Rome}

As might be expected, the significance given to the sundials in the papal and Jesuit gardens varies considerably between them, but in each case reflects perfectly the context for which the sundial was produced. As Marcello Fagiolo (2000) has argued, the tetracycle sundial in the papal gardens may be understood in the framework of the interest of both Urban VIII (Maffeo Barberini) and the Barberini family in scientific culture and astronomical theories. Specifically, Fagiolo's interpretation of the Quirinal gardens as an image of the "City of the Sun", administered under the enlightened and absolutist government of Pope Barberini, insists on the affinities existing between certain elements of the gardens and Tommaso Campanella's famous eponymous work written in 1602 and published for the first time in $1623 .^{25}$ In this sense, and for obvious reasons of propaganda, the sun is given a centrality within the gardens' imagery which is fully consonant with a sympathetic approach to heliocentrism. As such, it can be compared to similar works of art with astronomical subjects made for the pope, such as Andrea Sacchi's Allegory of Divine Wisdom in the Palazzo Barberini, painted between 1629 and 1633, probably according to a written programme devised by Campanella, in which, although the Earth looms large in the foreground, the Sun takes centre stage (Fig. 11). ${ }^{26}$ The chronology would fit with such an interpretation, since the placement of astronomical instruments in the papal garden around 1624-1628 corresponds to the very period during which Maffeo Barberini's accession to the papacy gave Galileo cause to hope for papal support. ${ }^{27}$ If we are to follow this interpretation, however, it must be emphasized that the heliocentrism discussed here referred to Galileo's theories only on a secondary level and that it was the propaganda value of the pope's heliocentric heraldry that was really decisive.

\footnotetext{
${ }^{25}$ On Campanella and Urban VIII, see further Bolzoni (2001).

${ }^{26}$ See Scott (1991: 38-94), for this work and the interest in astronomy and astrology among the Barberini circle, as well as the earlier work of Lechner (1976).

${ }^{27}$ (Fagiolo 2000: 227-229). On the relationship between Galileo and Urban VIII, see further Scott (2007).
} 


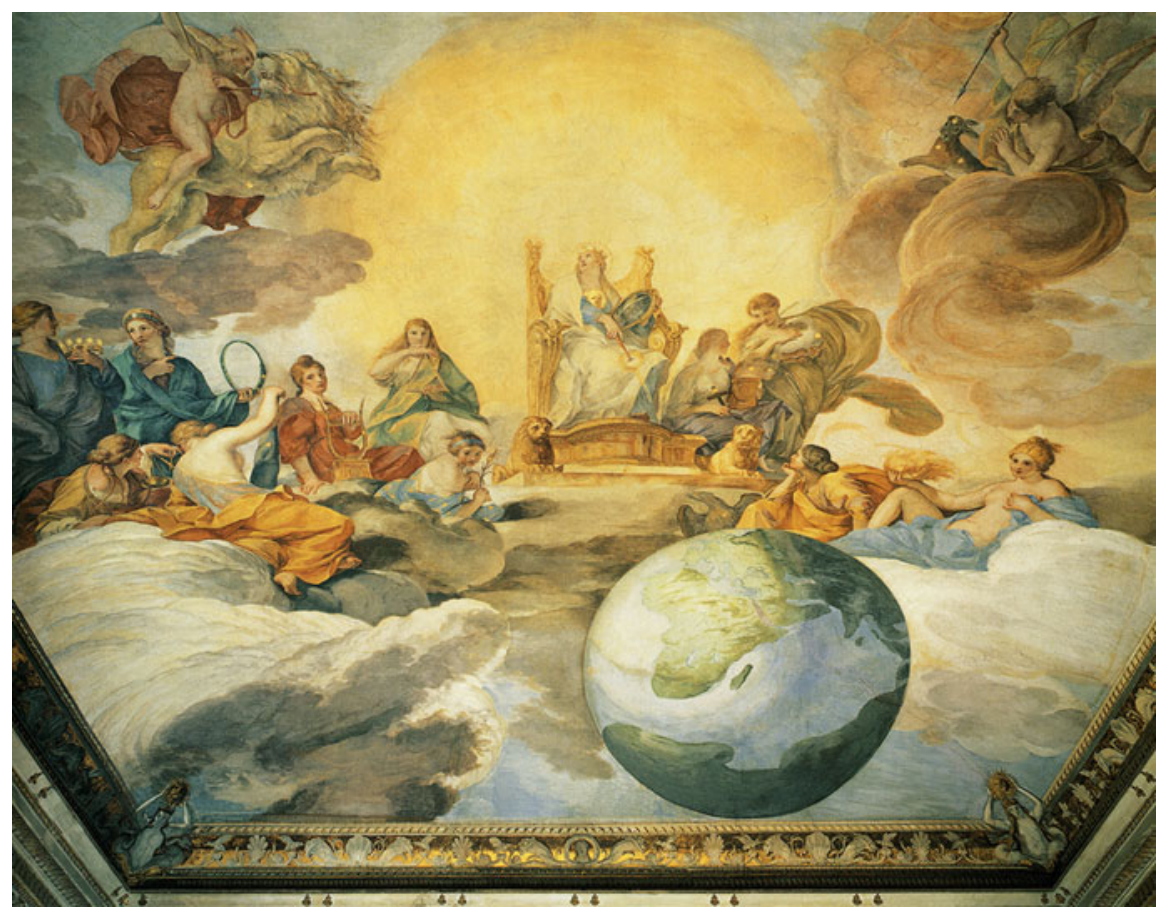

Fig. 11 Andrea Sacchi, Allegory of Divine Wisdom, Rome, Palazzo Barberini, 1629-1630, fresco, vault, (C) Wikimedia Commons. Image is in public domain

While still a cardinal, Maffeo Barberini, in a poem entitled Adulatio perniciosa, had praised the "lens" of the "learned Galileo" and his "skill" in using it to make new astronomical discoveries, but his position was no different from that of other prelates and members of the Church who posited the subordination of science to Holy Scripture. The fact that Tommaso Campanella stressed this passage of the poem in his Commentaria of 1628 provoked the ire of the pope, who was afraid of being associated with supporters of the Copernican theory (Bolzoni 2001: 265). ${ }^{28}$ Urban VIII wanted Galileo's prestige without accepting his most cherished beliefs. To be sure, the armillary spheres set in the garden, topped respectively by a cross and the pope's coat of arms, as can be seen in Giovan Battista Falda's engraving, were almost certainly geocentric Ptolemaic models, with the earth in the centre, not Copernican (Fig. 5b, c). ${ }^{29}$ In short, if the garden was indeed Galileo's panegyric, it was first and foremost the pope's universe.

\footnotetext{
${ }^{28}$ On the great difficulty of proclaiming heliocentrism in seventeenth century Rome, see further Beretta (2009).

${ }^{29}$ Most armillary spheres are constructed according to the Ptolemaic (geocentric) system and have a small terrestrial globe in the centre. Examples survive from medieval times to c. 1700, when a few Copernican (heliocentric) armillary spheres were made. Furthermore, the armillary spheres in
} 
To clarify this vexed issue of how astronomical sources were translated into encomiastic monuments, we may turn to an interesting - and I believe unpublished-Latin poem. In 1623, Ignazio Bracci, a Jesuit, protonotary apostolic and a friend of Federico Cesi and the members of the Accademia dei Lincei, published a book on the etymology of the pope's name, anticipating in a way the extraordinary publication in 1626 of Federico Cesi's Apiarium. The book, entitled La occulta corrispondenza tra l' arme, e 'l cognome de' Barberini, focuses on the bees and, like the Quirinal sundial with its rich heraldic decoration, is a celebration of the pope's good government. One poem is dedicated to Galileo; it is quoted here in English translation (Bracci 1623: 26):

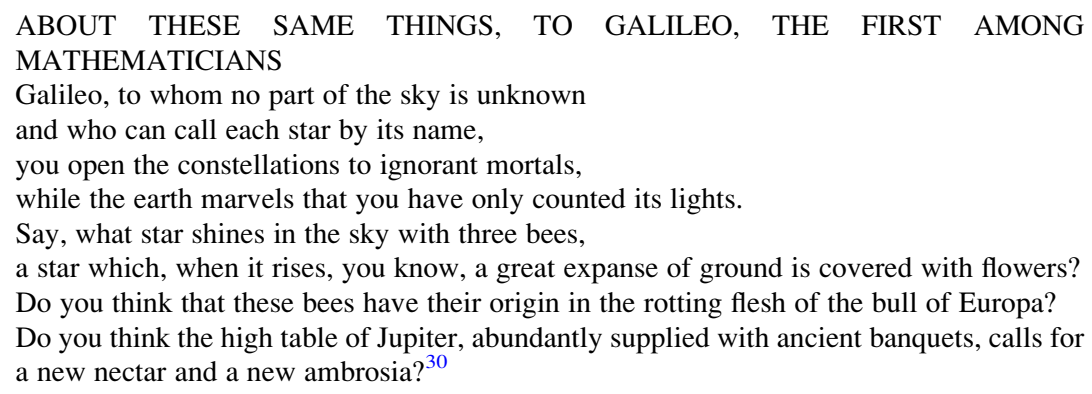

The mention of Europa's bull is a reference to the ancient belief that bees were born from the inside of the bull (bugonia), as explained in Virgil's Georgics (IV, 299-314 and 548-558). The association of this legend with the bull of Europa, however, is a modern invention and must be understood in light of Galileo's astronomical discoveries, in 1609, of Jupiter's satellites in the constellation of Taurus (in antiquity, the constellation represented Jupiter disguised as a bull after his rape of Europa). Semantically, the poem is thus constructed in a manner very similar to the Quirinal sundial. It celebrates Galileo's scientific discoveries by using ancient sources, notably Virgil, but is essentially aimed at celebrating the pope's power and the dawn of a new golden age, a new era of abundance and prosperity made explicitly visible in the magnificent papal gardens. In both examples, the heraldic symbols of the pope are the pivotal elements in the construction of meaning.

Now let us return to Richeome's exegesis of Christoph Clavius' sundials in the Jesuit garden. Richeome uses two important biblical sources relating astronomical miracles to explain to the novices and to garden visitors how those sundials should be

Falda's engraving have a tilted cage and a large horizontal band representing the horizon, which is typical of Earth-centred armillary spheres and is often missing when the Sun occupies the centre. 30 “DE EISDEM, AD MATHEMATICORVM / Principem Galilaeum. Pars caeli quem nulla latet, Galilaee, potesque / Nomine qui, stellas dicere quamque suo, / Sideraque ignaris aperis mortalibus, unum / Mirante orbe suas te numerasse faces. / Dic age, quodnam apibus caelo tribus emicat astrum, /Quo exoriente, vide'n, plurima floret humus? / Anne Europaei dissecto viscere tauri / Ortum credis apes has habuisse suum? / An Iovis alta, putas, dapibus saturata vetustis / Nectar mensa novum poscit, \& ambrosiam?" I thank Lise Ottis for her help in translating and interpreting this passage. 
understood: the story of the Sun standing still in Joshua 10:12, and that of the Sun reversing its course in 2 Kings 20: 8-11, also known as Horologium Ahas. What is especially interesting here is that these were the main sources used by Jesuit theologians to reject the Copernican theory of terrestrial motion, as Volker R. Remmert (2006, 2011) has shown, and that they were used for the same reason by Clavius himself, first in his Sacrobosco commentary of 1570 and again as illustrations on the title-page of his Opera mathematica of 1612 (Fig. 12). It is likely that Richeome knew this from Clavius' works, or even directly from Clavius himself, and that the novices propounded those same arguments to the students and pilgrims who visited the garden. ${ }^{31}$ As in the papal gardens, it thus appears that the debate about Copernican theories had a bearing on the way those sundials were used and understood. Nonetheless, I would argue that the scientific debate does not seem to have been the main point here, only an implied one. Richeome-like Clavius on his title-page-does not fully decode the implicit meaning of these biblical references. In the same way that the sundial becomes the object of heraldic praise in the papal gardens, relegating the question of its link with heliocentrism to mere conjecture, Richeome is primarily interested in the moral dimension of the sundials, which takes up the whole of the second section he dedicates to sundials in his book. The sundial is presented as a reminder of the inevitability of death, at which point the precise measure of time becomes totally irrelevant. Thus, for Richeome (1611: 501-502), one must above all follow "the Divine Sun Jesus Christ", which "does not set for those who want to be wakeful and fight like brave Joshua, who stopped the course of the Sun". Time, quadrants and sundials will be useless, he concludes, for those who have entered victoriously into the "city of light", for eternity. ${ }^{32}$

\footnotetext{
${ }^{31}$ The garden and its ornaments were used by the Novices for teaching the Christian doctrine. In the engraving by Greuter, we see children and visitors being guided and taught in the different parts of the garden (Fig. 9). On this educational dimension of the Jesuit garden, see Witte (2011: 102-106). 32 "Donc, selon les divers points de ces horloges diverses, les vingt-quatre heures finissent, au levant, au couchant, au midi, et à la minuit; Et selon le cours des horloges de la vie humaine, elles peuvent finir à chaque heure du jour, sans avoir égard aux cadrans, et points artificiels du jour: Car quand la mort viendra soit à dix heures, soit à douze, soit à quatorze ou à vingt, soit à midi, ou à la minuit; à la Diane, ou à la serée [sic], voilà nos vingt-quatre heures passées, et notre Soleil couché, et notre jour mortel, et naturel fini; et partant, mes bien aimés, tenons-nous prêts à chaque point du jour, à chaque heure, voire à chaque minute; Car à tous points nous pouvons mourir; Et comme fleurs Héliotropes de sens, et de raison, suivons le Soleil divin Jésus-Christ, qui ne couche point pour ceux, qui veulent veiller, et combattre à guise de vaillants Josué, qui arrêta le Soleil pour avoir son jour à grande mesure, et donner à souhait contre les ennemis de Dieu, et demeurant maitres du champ, emporter la victoire entière; suivons ses conseils et avertissements, afin qu'en la lumière de sa grâce, nous voyions le chemin de salut, voyions nos ombres, nos heures, et nos inconstances, nos vanités, nos imperfections grandes, et petites, et ayant la victoire de nous-même, marchant toujours avec notre Soleil, et faisant toujours progrès à la vertu envers Dieu, et gardons-nous d'être surpris de la nuit; Afin que quand cette nuit viendra, et qu'il faudra quitter la vie de ce corps, et sortir de l'inconstance du temps coulant, nous entrions victorieux en la cité de lumière, au pourpris [sic] de l'éternité permanente, et recevions la couronne de gloire, qui vole par dessus les cadrans, et les temps, et les siècles des siècles". Interrestingly here, the use of sundials runs parallel to the moralizing interpretations that David Coffin sees in English sundials and in the English emblem literature. Coffin (1994: Chap. I).
} 


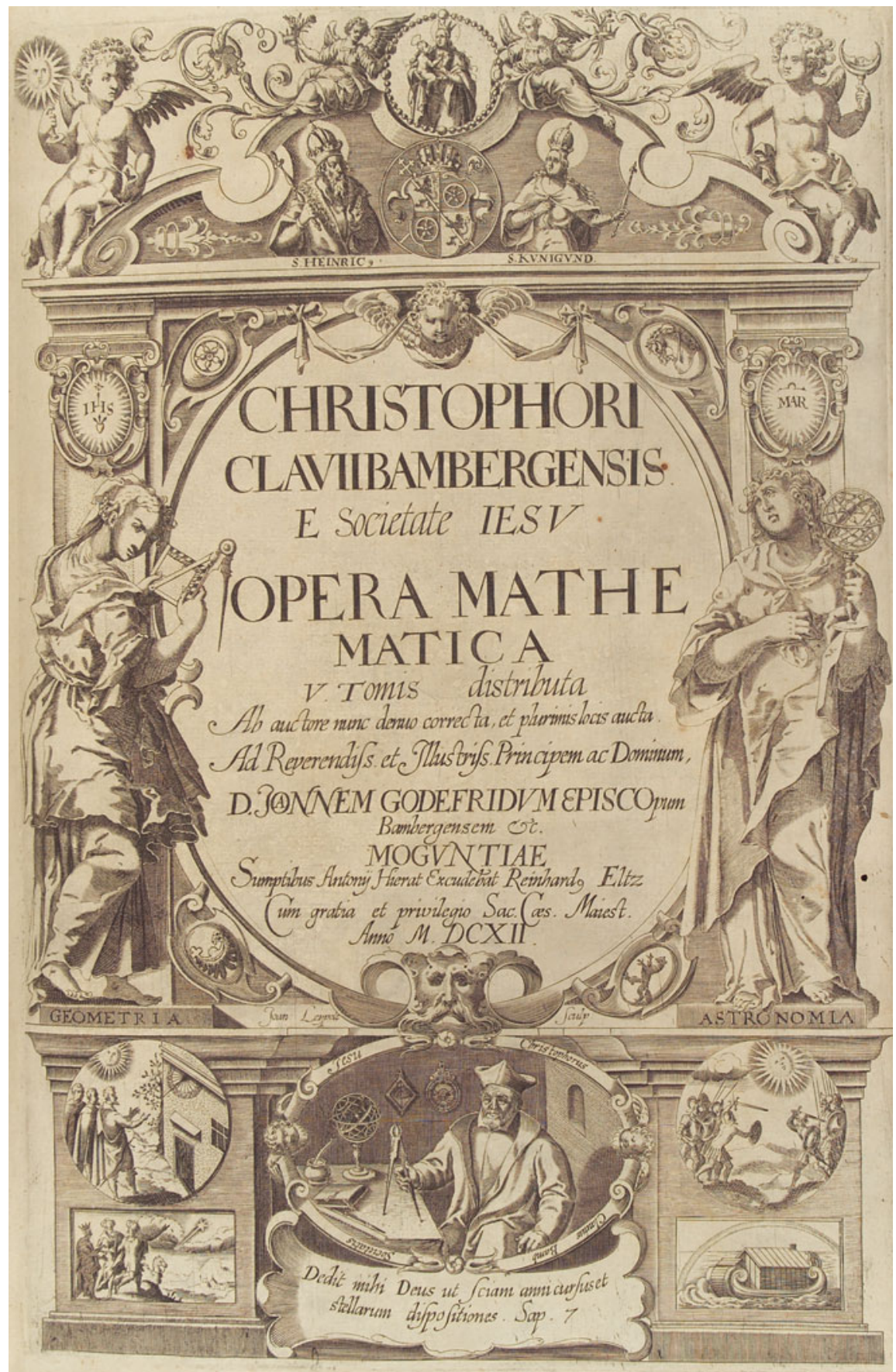

Fig. 12 Frontispiece to Christoph Clavius, Opera mathematica, 1612, (C) from Remmert $(2011,75)$ 


\section{The Image of the Sundial as an Architectural Source?}

Before leaving the Quirinal hill, one should note that the importance of astronomical measurements - especially sundials - for the Jesuits may have had an impact on the architecture of the main church of the Noviciate adjacent to the garden. The church of Sant'Andrea del Quirinale, conceived by Gianlorenzo Bernini and Pope Alexander VII Chigi, was built much later, between 1658 and 1672, on the site of the former chapel of the Noviciate. Concerning Bernini's famous oval plan for the church, Geraldine Dunphy Wind (2013) has observed a "remarkable congruence of the radial unity of Bernini's Church and geometric properties found in Vitruvius's instructions for making a sundial, described in his De architectura" (IX, 7 and 2-7). ${ }^{33}$ According to her reading, the entire plan is strictly based on the image of the Vitruvian sundial or Alemma, a hypothesis which would fit with the solar appearance of the vault itself, with its ribs and the illuminated central lantern (Fig. 13). The image of the sundial would have had deep symbolic meaning. It celebrated Pope Chigi, who also used solar imagery, and functioned as part of the Jesuit poetics of light, entering into dialogue not only with the various sundials, obelisks, flowers and plants in the adjacent garden, but above all with the other main iconographic elements of the church, namely the 'heliotropic' Saint Andrew ascending into heaven. ${ }^{34}$ The staging or 'phenomenology of light' (Fagiolo 2013: 113) at Sant'Andrea indeed recalls, Dunphy Winds (2013) argues, the text from the liturgy for Saint Andrew's feast day, which is central to the entire program of the church: "An exceeding Bright light (luce perfusus) surrounds him for nearly a half an hour and then in this light (cum luce), and in this joy, he mounts to the realms of light (lucis atria)" (Dunphy Wind 2013: 22).

Although the idea is appealing, there is no hard evidence to prove that Bernini designed the church with Vitruvius's sundial in mind. What Dunphy Wind's argument demonstrates, at best-and this is what is most interesting to us-is that it is possible that Jesuit novices and other people familiar with sundials made that connection, whether it was intended or not. They knew the sundials that had been in the garden for at least half a century and had been exposed to the long Jesuit tradition of astronomical studies, of which they had almost certainly learned at least the first principles in the course of their apprenticeship.

The Jesuit novices at Sant'Andrea del Quirinale would have been taught astronomy and mathematical sciences at the nearby Collegio Romano, the most important centre of astronomical research in Rome together with the monastery of the Minim friars at Trinità dei Monti. Such was the case, for example, of Orazio Grassi, who entered the novitiate of Sant'Andrea in 1600 and then studied at the Collegio Romano between 1603 and 1610 with Clavius, Christoph Grienberger and Odo van Maelcote. Grassi was not only well versed in astronomy (Tractatus tres de

\footnotetext{
${ }^{33}$ On the planning of the church, see Connors (1982).

${ }^{34}$ For a thorough reading of the iconographic programme of Sant'Andrea, see Careri (1990: 149-183).
} 


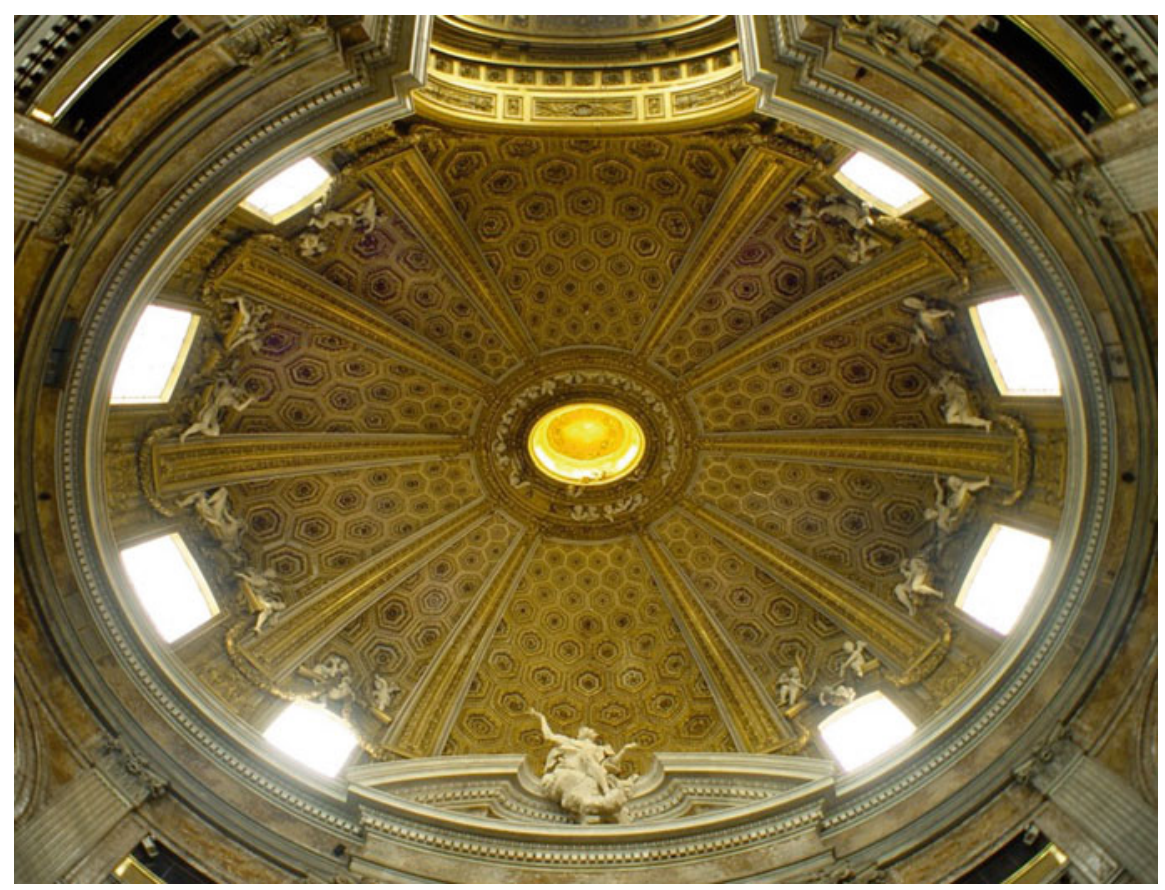

Fig. 13 Gianlorenzo Bernini, Antonio Raggi, Vault of the church of Sant'Andrea al Quirinale, Rome, 1661-1666, (C) Wikimedia Commons. Image is in public domain

sphera, de horologis ac de optica, 1617) and a fierce opponent of Copernican theories and Galileo, but was also expert in architecture-as consiliarius aedificiorum he supervised the construction of every building for the Company of Jesus and especially that of Sant'Ignazio. He published a treatise on Vitruvius' chapter on sundials In primum librum de architectura M. Vitruvii et in nonum eiusdem de horologiorum solarium descriptione duo brevissimi tractati, in 1624 (Milan, Biblioteca nazionale Braidense, AF.IX.33). This chapter is the source, according to Dunphy Wind's proposal, of the oval plan of the church of Sant'Andrea. Grassi is also known to have carried out thorough research into the physics of light. Since he died in 1654, he could not have been responsible for this idea, but, again, his work demonstrates the plausibility of establishing links between astronomy and architecture in early modern Rome. ${ }^{35}$

Piazza San Pietro is another case in point. Since the time of Sixtus V, when the obelisk was re-erected in the center of the Piazza, plans had been formed to turn the huge monument into the needle of a large sundial, based on the prestigious model of the Horologium Augusti (Avviso di Roma of December 24, 1588; D’Onofrio 1967:

\footnotetext{
${ }^{35}$ Further on Orazio Grassi, see Presti and Ercolino (2002) and Bösel (2004).
} 


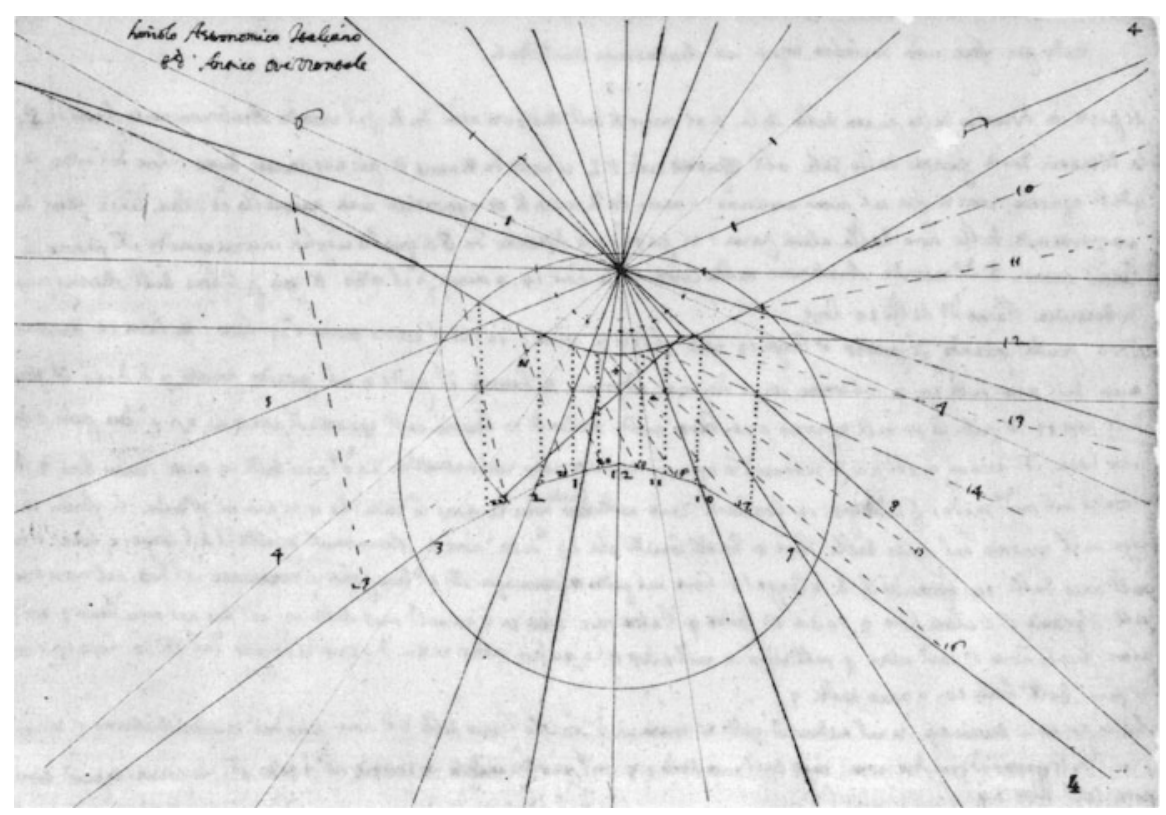

Fig. 14 Fabio Chigi (Alexander VII), Drawing of a sundial, Biblioteca Apostolica Vaticana, Chig. A I 18, f. 4 (from Morello 1992: Fig. 2)

90). ${ }^{36}$ Again, in a letter dated from 1667 to Cardinal Giacomo Filippo Nini, Athanasius Kircher suggested creating 'l'horologio più grande del mondo' (Bartola 1989: 99) on Piazza San Pietro and this grandiose idea was given graphic form in Cornelis Meyer's book of 1685 (Pl. XV) (Fig. 15). We know that Fabio Chigi (Alexander VII) himself had a deep interest in gnomonics. For instance, he left us a drawing of a sundial probably based on Augustus's sundial in the Campomarzio (BAV Chig.a.I.18, f. 4; Morello 1992: Fig. 2) (Fig. 14). This has led some art historians to suggest that the pope, with the genial help of Bernini, conceived the great oval of Piazza San Pietro as a magnificent sundial, or 'Theater of the Sun', "for the measure of time and space, with its obelisk conceived as both a gnomon and axis mundi" (Fagiolo 2013: 115-121). In truth, only in November 1817 would a meridian line be built and the obelisk used as a gnomon. ${ }^{37}$ As for Sant'Andrea del Quirinale, Alexander VII's interests in the sun and sundials cannot explain in itself the entire conception of Piazza San Pietro, but it points to the possibility that he and some of his contemporaries could imagine it functioning as a sundial. This leap

\footnotetext{
${ }^{36}$ See also s.a. Piazza San Pietro (2007).

37 "A cura di môns. Gilii, astronomo vaticano, venne disegnata una meridiana per movimenti mensili e giornalieri del sole all'ora del meriggio, alla quale questo obelisco serve di gnomone". See D’Onofrio (1967: 90).
} 


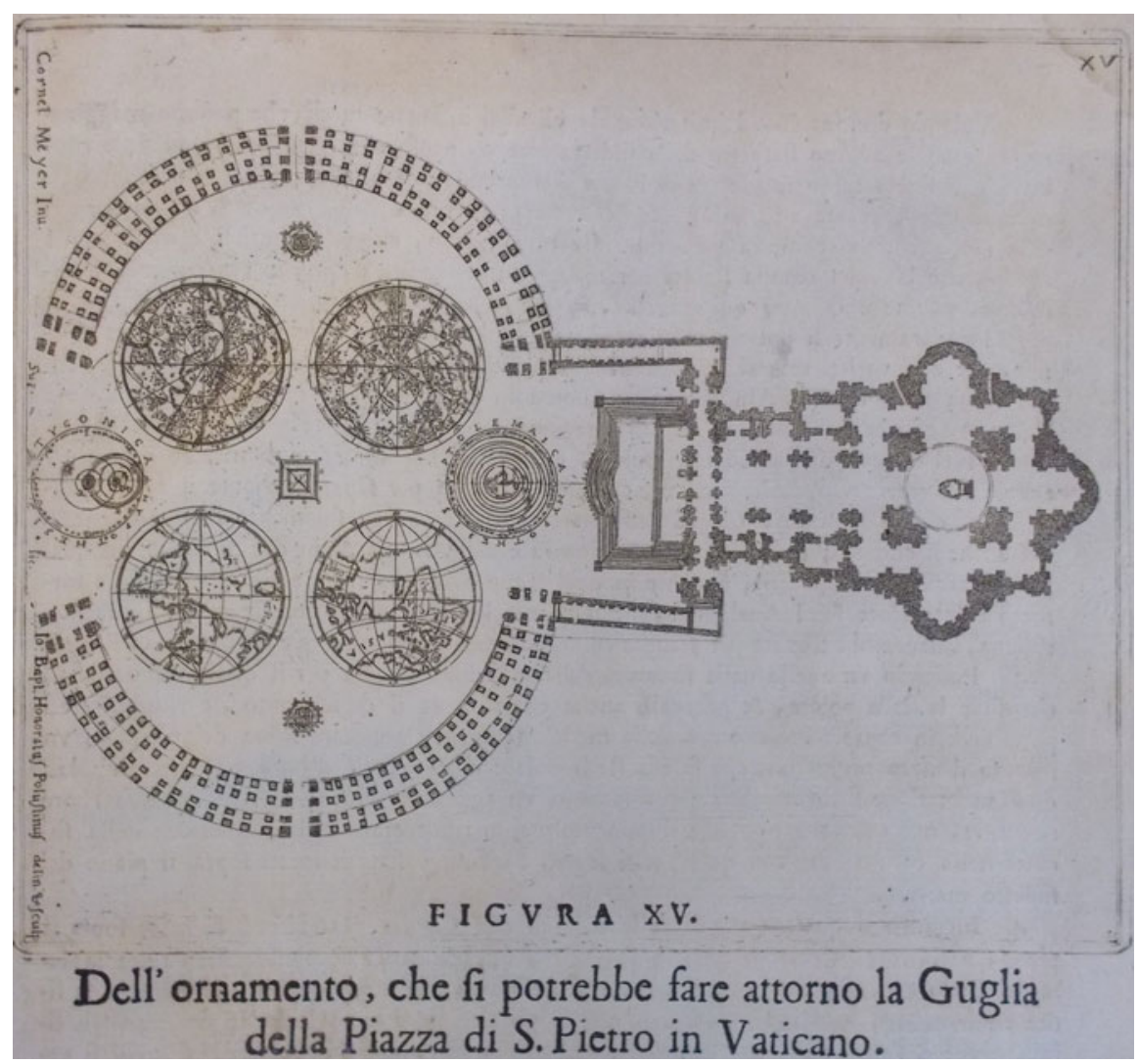

Fig. 15 Gaspar Van Wittel (?), Project for Piazza San Pietro, in Cornelis Meyer, Arte di restituire a Roma la tralasciata navigazione del Tevere, Rome, 1685, pl. XV, (C) Photo author

from the world of concrete appearances to that of the scientific and curious imagination is exactly what Cornelis Meyer's wonderful book of 1685 makes tangible.

\section{Conclusion}

The study of mathematical instruments used as garden ornaments offers an interesting occasion to question the interaction between the history of material culture and the history of theories and ideas. Sundials are, primarily, useful instruments to measure time but, in the early modern period, they were also 'useful' in many other ways, as objects of meditative practices, as teaching tools or as encomiastic monuments. To borrow Koen Vermeir's conclusion about Athanasius Kircher's clocks and sundials and their metaphysical meaning, they were "at once measuring instruments and representations of political and metaphysical meanings [...] 
meanings related with entertainment, spectacles and courtly culture" (Vermeir 2007: 394). Michel Serres makes an even stronger statement: "[T]he gnomon or sundial is less useful as an instrument to tell the time of day, one which nobody has cared about between Antiquity and our grandparents' time, than it is as a geometrical model of the Universe: at the same time an observatory and a cosmographic schema of the world". ${ }^{38}$ In the case of the Quirinal sundials we have discussed, their central presence in large and famous gardens is obviously linked with the scientific debates that took place during this period, and more specifically with important astronomers such as Galileo or Christoph Clavius, who had direct associations with those places. Yet, by becoming a part of the gardens, these sundials took on meanings which added a new complexity to their connection with the world of professional scientists. The scientific aspect of the instruments somehow became entangled with - and perhaps even secondary to-their essentially symbolic, propagandistic or moral function. In this sense, gardens, with their astronomical imagery, can be compared in many ways to the title-pages of early modern mathematical and astronomical books. They shaped the way users or viewers understood Nature and the Universe, reminding them that the main goal of science, even in its most refined applications, must be the search for God and the building of a new Paradise.

Besides provoking wonder and delight, like an automaton, a marvellous fountain or a precious statue, these mathematical instruments materialized a fundamental connection between Heaven and Earth, between Nature as God's infinite cosmic creation and nature in the garden. ${ }^{39}$ Being derived from mathematical knowledge, they echoed the geometrical features of the garden and emphasized the human capacity not only to rule over nature but also to explore the boundless sky. They boosted the owners of these gardens as patrons of the sciences and, most importantly, I believe, provided elite non-scientists-for instance, Urban VIII or Alexander VII-with an opportunity to "talk about science", to convey what was truly important about their engagement with science, a discourse-about which was of primary importance in the early modern period. ${ }^{40}$ In Stefano Guazzo's La civil conversazione, one of the key manuals on social behaviour of the time, "knowledge begins in conversation and ends in conversation" (Guazzo 1993: I, 30). In the same way that discourse-about painting and discourse-about music became central as a badge of identity for the social elite, one may argue that discourse-about science, and astronomy in particular, was also of great importance for the creation

\footnotetext{
${ }^{38}$ Serres (1986): "Le gnomon ou cadran solaire sert moins à dire l'heure dont tout le monde se moque depuis l'Antiquité jusqu'à nos grands-parents, qu'à construire un modèle géométrique del'Univers: observatoire à la fois et schéma cosmographique du monde". Further on this issue, see Mosley (2006).

${ }^{39}$ On the role of entertainment and public enjoyment in the development of early modern technology, see Findlen (1990) and Bredekamp (1995: 69-80).

${ }^{40}$ For a recent and thorough discussion of science in early modern Rome, see Romano (2009), with ample bibliography.
} 
of meaning in the early seventeenth century. Speaking of music, Andrew Dell'Antonio has remarked (2011: 6):

\begin{abstract}
Effective discourse-about (a marker of the civilized conversationalist) enables a change in the status of the object-indeed, in the case of music, encourages the idea that music (through careful assessment of the listener's experience) can somehow be "objectified" as an item for discussion. More importantly, discourse-about also brings attention to discourse as crucial to the creation of status and meaning (though the discourse itself may ostensibly be a transparent account of the item under discussion). Thus the sophisticated or elevated nature of the discourse can be seen as more important than its "objectivity" or "accuracy" (in technical terms) concerning the item around which discourse is taking place.
\end{abstract}

An interpretative framework of this kind could prove especially useful for discussing the iconography of and on (that is, a form of discourse-about on) scientific instruments and their link with larger decorative and/or architectural ensembles, such as the magnificent gardens of Rome that Galileo had appreciated so much in 1611.

\title{
Bibliography
}

\section{Sources}

Baglione, Giovanni. 1642. Le Vite de' pittori, scultori et architetti. Dal pontificato di Gregorio XIII nel 1572 in fino a' tempi di Papa Urbano Ottavo nel 1642. Rome.

Bracci, Ignatio. 1623. La occulta corrispondenza tra l'arme e il cognome dei Barberini. Roma: Per Guglielmo Facciotti.

Fabricii, Principio. 1588. Delle allusioni, imprese, et emblemi del Sig. Principio Fabricii da Teramo sopra la vita, opere, et attioni di Gregorio XIII. Pontefice massimo, Libri VI. Nei quali sotto l'allegoria del Drago arme del detto Pontefice si descrive anco la vera forma d'un Principe Christiano; et altre cose, la somma della quali si legge dopo la dedicatione dell'opera all'Ill(ustrissi)mo et Ecc(ellentissi)mo S(igno)r Duca di Sora. Rome: Bartolomeo Grassi.

Galileo, Galilei. 1890-1909. Opere di Galileo Galilei. Ed. Antonio Favaro. Firenze: G. Barbèra.

Kircher, Athanasius. 1646. Ars magna lucis et umbrae. Rome.

Kircher, Athanasius. 1650. Musurgia universalis, sive ars magna consoni et dissoni. Rome.

Line, Francis. 1673. An explanation of the Diall sett up in the King's garden in 1669 / Explicatio Horologii in Horto Regio Londini in Anglia an. 1669. erecti, in quo plurima horologiorum sciatericorum genera continentur : quibus praeter omnis generis horas diversimode expressas, multa etiam ad Geographiam Astrologiam et Astronomiam spectantia, per Solis umbram oculis cernenda subjiciuntur. Inter quae, plurima, et potissime magis curiosa, noviter inventa, et a nemine hactenus tradita reperiuntur. Quae omnia breviter et dilucide publicae utilitati exponit Reverendus Pater Franciscus HALLUS, alias Linus Societatis Jesu, Matheseos professor. Liège: Streel [Coll. Univ. Liège, I. 105.2].

Menestrier, Claude François. 1663. Le Temple de la sagesse ouvert à tous les peuples. Lyon: Chez Antoine Molin.

Meyer, Cornelius. 1685. Arte di restituire a Roma la tralasciata navigazione del Tevere. Rome: s.n.

Richeome, Louis. 1611. La peinture spirituelle ou l'Art d'admirer aimer et louer Dieu en toutes ses oeuvres, et tirer de toutes profit salutere.... Lyon: Pierre Rigaud.

Scheiner, Christoph. 1630. Rosa Ursina. Braccianum: s.n. 


\section{Secondary Literature}

s.a., 2007. Piazza San Pietro: una meridiana e una rosa dei venti per la Basilica Vaticana. La Basilica di S. Pietro 19: 1-2.

Aksamija, Nadja. 2011. The Emblem Book as the World Reformed: Symbolic Landscapes in Principio Fabricii's Delle allusioni, imprese, et emblemi. In Sacred Landscape. Landscape as Exegesis in Early Modern Europe, eds. Denis Ribouillault and Michel Weemans, 133-159. Florence: Olschki.

Angelucci, Sergio. 1991. La lancetta dell'orologio: restauro e significati. Bolletino d'arte 66: 101-103.

Angelucci, Sergio. 1993. Il tempo del drago. L'orologio di Sant'Atanasio dei Greci a Roma. Art \& Dossier 80: 38-41.

Bailey, Gauvin Alexander. 2003a. Between Renaissance and Baroque: Jesuit Art in Rome, 15651610. Toronto et al.: University of Toronto Press.

Bailey, Gauvin Alexander. 2003b. La contribution des jésuites à la peinture italienne et son influence en Europe 1540-1773. In L'art des Jésuites, ed. G. Sale, 123-168. Paris: Mengès.

Barbieri, Patrizio. 1981. L'organo idraulico del Quirinale. L'Organo 19: 7-61.

Bartola, Alberto. 1989. Alessandro VII e Athanasius Kircher S.J. Ricerche ed appunti sulla loro corrispondenza erudita e sulla storia di alcuni codici chigiani. Miscellanea Bibliothecae Apostolicae Vaticanae 3: 7-105.

Beaven, Lisa. 2007. Claude Lorrain's Harbour Scenes: Sun, Science and the Theatre in the Barberini Years. In Art, Site and Spectacle: Studies in Early Modern Visual Culture, ed. D.R. Marshall, 146-161. Melbourne: Fine Arts Network.

Beretta, Francesco. 2009. L'héliocentrisme à Rome, à la fin du XVIIe siècle: une affaire d'étrangers?. In Rome et la science moderne entre Renaissance et lumières, ed. A. Romano, 529-554. Rome: École française de Rome.

Bolzoni, Lina. 2001. Urbano VIII, Campanella e la censura dei 'Commentaria'. In Il piacere del testo. Saggi e studi per Albano Biondi, ed. Adriano Prosperi, 265-284. Rome: Bulzoni editore.

Bösel, Richard. 2004. Orazio Grassi: architetto e matematico gesuita; un album conservato nell'archivio della Pontificia Università Gregoriana a Roma. Rome: Argos.

Bredekamp, Horst. 1995. The Lure of Antiquity and the Cult of the Machine. The Kunstkammer and the Evolution of Nature, Art and Technology. Princeton: Markus Wiener.

Camerota, Filippo. 2000. La meridiana tetracycla del Quirinale. In Francesco Borromini, eds. Christoph L. Frommel and Elisabeth Sladek, 233-241. Milan: Electa.

Careri, Giovanni. 1990. Envols d'amour: le Bernin; montage des arts et dévotion baroque. Trad. Michelle Coquet. Florence: Usher.

Coffin, David. 1991. Gardens and Gardening in Papal Rome. Princeton: Princeton University Press.

Coffin, David. 1994. The English Garden. Meditation and Memorial. Princeton: Princeton University Press.

Connors, Joseph. 1982. Bernini's S. Andrea al Quirinale: Payments and Planning. The Journal of the Society of Architectural Historians 41: 15-37.

Connors, Joseph. 2015. The One-room Apartment of Cornelis Meijer. In Artistic Practices and Cultural Transfer in Early Modern Italy: Essays Dedicated to Deborah Howard, eds. Nebahat Avcıoğlu and Allison Sherman, 45-64. Burlington VT: Ashgate.

Courtright, Nicola. 2003. The Papacy and the Art of Reform in Sixteenth Century Rome. Gregory XIII's Tower of the Winds in the Vatican. Cambridge: Cambridge University Press.

Davidson, Peter. 2006. The Jesuit Garden. In The Jesuits II. Cultures, Sciences, and the Arts, 15401773, ed. John O'Malley, 86-107. Toronto et al.: University of Toronto Press.

Dekoninck, Ralph. 2005. 'Ad imaginem': Statuts, fonctions et usages de l'image dans la littérature spirituelle jésuite du XVIIe siècle (Travaux du Grand Siècle, 26). Genève: Droz.

Dell'Antonio, Andrew. 2011. Listening as Spiritual Practice in Early Modern Italy. Berkeley, Los Angeles, London: University of California Press. 
D’Onofrio, Cesare. 1967 (1965). Gli obelischi di Roma. Roma: Bulzoni editore.

Fabre, Pierre-Antoine. 1995. Lieu de mémoire et paysage spirituel. In Le jardin, art et lieu de mémoire, eds. M. Mosser and P. Nys, 135-148. Besançon: Éditions de l'Imprimeur.

Fagiolo, Marcello. 1998. I giardini papali del Vaticano e del Quirinale. In Giardini Regali, Fascino e immagini del verde nelle grandi dinastie: dai Medici agli Asburgo, ed. Monica Amari, 69-80. Milan: Electa.

Fagiolo, Marcello. 2000. Il segno del giovane Borromini nella 'Città del Sole' di Urbano VIII (1624-1631). In Francesco Borromini, eds. Christoph L. Frommel and Elisabeth Sladek, 215-232. Milan: Electa.

Fagiolo, Marcello. 2013. Bernini e il 'gran teatro' della Roma barocca. In Roma barocca. I protagonisti, gli spazi urbani, i grandi temi, ed. Marcello Fagiolo, 97-125. Roma: De Luca.

Fagiolo, Marcello. 2014. Roma di Innocenzo XI: la città, la scienza, le feste e l'incontro con Le Nôtre. In Innocenzo XI Odescalchi. Papa, politico, committente, eds. Richard Bösel et al., 275-288. Rome: Viella.

Findlen, Paula. 1990. 'Quanto scherzevole la natura'. La scienza che gioca dal Rinascimento all'Illuminismo. Intersezioni. Rivista di Storia delle Idee 3: 413-436.

Frommel, Christoph Luitpold. 1999/2002. Il palazzo del Quirinale tra il XV e il XVII secolo. Quaderni dell'Istituto di Storia dell'Architettura, 34/39: 275-284.

Galluzzi, Paolo. 2009. Galileo e gli ‘spettacoli del cielo’ sul colle del Quirinale. Il Quirinale 5: 81-90.

Gijsbers, P.-M. 1999. Claudio Aquaviva, Louis Richeome, and Durante Alberti's Altarpiece for Sant'Andrea al Quirinale. In Docere, delectare, movere: affetti, devozione e retorica nel linguaggio artistico del primo baroco romano, 27-40. Rome: De Luca.

Godwin, Joscelyn. 1979. Athanasius Kircher: A Renaissance Man and the Quest for Lost Knowledge. London: Thames and Hudson.

Guazzo, Stefano. 1993. La civil conversazione (1574). Ed. Amedeo Quondam, 2 vols. Ferrara: Franco Cosimo Panini.

Guiderdoni-Bruslé, Agnès. 2001. Les formes emblématiques de 'l'humanisme dévot': une lecture du 'Catéchisme royal' (1607) de Louis Richeome, S.J. In An Interregnum of the Sign: The Emblematic Age in France. Essays in honour of Daniel S. Russell (Glasgow Emblem Studies, 6), ed. D. Graham, 227-235. Glasgow: University of Glasgow.

Harris, Steven J. 1999. Mapping Jesuit Science: The Role of Travel in the Geography of Knowledge. In The Jesuits: Cultures, Sciences, and the Arts, 1540-1773, ed. John W. O’Malley, vol. 1, 212-240. Toronto et al.: University of Toronto Press.

Heilbron, John L. 1999. The Sun in the Church. Cathedrals as Solar Observatories. Cambridge: Harvard University Press.

Höltgen, Karl Joseph. 2004. The Illustrations of Louis Richeome's 'La peinture spirituelle' (1611) and Jesuit Iconography. In Florilegio de Estudios de Emblemàtica, ed. S. López Poza, 447-458. El Ferrol: Sociedad de Cultura Valle Inclàn.

Iversen, Erik. 1968. The Obelisks of Rome. In Obelisks in Exile, vol. 1. Copenhagen: G.E.C. Gad Publishers.

Lattis, James M. 1994. Between Copernicus and Galileo: Christoph Clavius and the Collapse of Ptolemaic Cosmology. Chicago: University of Chicago Press.

Lechner, George S. 1976. Tommaso Campanella and Andrea Sacchi's Fresco of Divina Sapienza in the Palazzo Barberini. The Art Bulletin 58: 96-108.

Loach, Judi. 2012. An apprenticeship in 'spiritual painting'. Richeome's La peinture spirituelle. In Ut pictura meditatio. The Meditative Image in Northern Art, 1500-1700, eds. Walter S. Melion, Ralph Dekoninck and Agnes Guiderdoni-Bruslé, 337-399. Turnhout: Brepols.

Macioce, Stefania. 1990. Undique splendent: Aspetti della pittura sacra nella Roma di Clemente VIII Aldobrandini. Rome: De Luca edizioni d'arte.

Macioce, Stefania. 1995. Aspetti simbolici nel giardino del noviziato di S. Andrea al Quirinale in Roma. In Memor fui dierum antiquorum: Studi in memoria di Luigi di Biasio, ed. P.C. Ioly Zorattini, 381-395. Udine: Camponotto. 
Mancinelli, Fabrizio, and Juan Casanovas. 1980. La Torre dei venti in Vaticano. Vatican city.

Meadows-Rogers, Robert D. 1996. The Vatican Logge and their Culminating Decorations under Pius IV and Gregory XIII: Decorative Innovation and Urban Planning before Sixtus V. Ph. D. University of North Carolina.

Morello, Giovanni. 1992. I rapporti tra Alessandro VII e Gian Lorenzo Bernini negli autografi del Papa (con disegni inediti). In Documentary Culture. Florence and Rome from Grand-Duke Ferdinand I to Pope Alexander VII, eds. E. Cropper and G. Perini, 185-207. Bologna: Nuova Alfa Ed.

Mosley, Adam. 2006. Objects of Knowledge : Mathematics and Models in Sixteenth-Century Cosmology and Astronomy. In Transmitting Knowledge: Words, Images, and Instruments in Early Modern Europe, eds. S. Kusukawa and I. Maclean, 193-216. Oxford: Oxford University Press.

Pliny. 1940. Natural History. Trans. H. Rackham. Cambridge: Harvard University Press.

Presti Cesare, Ercolino Maria Grazia. 2002. Orazio Grassi. Dizionario biografico degli italiani, 58. http://www.treccani.it/enciclopedia/orazio-grassi_\%28Dizionario-Biografico\%29/. Accessed 15 September 2013.

Quiviger, François. 2003. Honey from Heaven: Aspects of the Topos of the Bees in Renaissance Artistic Literature. In Visuelle Topoi. Erfindung und tradiertes Wissen in den Künsten der italienischen Renaissance, eds. Ulrich Pfisterer and Max Seidel, 317-321. München-Berlin: Deutscher Kunstverlag.

Reilly, Connor. 1962. Francis Line, Peripatetic (1595-1675). Osiris 14: 222-253.

Reilly, Connor. 1969. Francis Line SJ: An Exiled English Scientist, 1595-1675. Rome: Institutum historicum S.I.

Remmert, Volker R. 2006. Picturing Jesuit Anti-Copernican Consensus. Astronomy and Biblical Exegesis in the Engraved Title-page of Clavius's Opera mathematica (1612). In The Jesuits II. Cultures, Sciences, and the Arts, 1540-1773, ed. John O' Malley, 291-313. Toronto et al.: University of Toronto Press.

Remmert, Volker R. 2011. Catholic Biblical Exegesis and the Origins of the Galileo Affair: The Engraved Title Page of Clavius's Opera mathematica (1612). In Picturing the Scientific Revolution: Title Engravings in Early Modern Scientific Publications, 17-45. Philadelphia: Saint Joseph's University Press.

Romano, Antonella (ed.). 2009. Rome et la science moderne entre Renaissance et Lumières. Rome: École française de Rome.

Ruffini, Marco. 2005. Le imprese del drago: Politica, emblematica e scienze naturali alla corte di Gregorio XIII (1572-1585). Rome: Bulzoni editore.

Sauvenier-Goffin, Elisabeth. 1958. Une page de l'enseignement des sciences exactes de l'ancien pays de Liège: le tractatus de horologiis du Père Linus. Bulletin de la Société Royale des Sciences de Liège $27^{\mathrm{e}}$ année, 11-12: 280-284.

Scott, John Beldon. 1991. Images of Nepotism: the Painted Ceilings of Palazzo Barberini. Princeton: Princeton University Press.

Scott, John Beldon. 2007. Galileo and Urban VIII. Science and Allegory at Palazzo Barberini. In I Barberini e la cultura europea del Seicento, eds. L. Mochi Onori, S. Schütze and F. Solinas, 127-136. Roma: De Luca.

Serres, Michel. 1986. Gnomon. Les débuts de la géométrie en Grèce. In Éléments d'histoire des sciences, ed. Michel Serres, 95-153. Paris: Bordas.

Shea, William R., and Mariano Artigas. 2003. Galileo in Rome. The Rise and Fall of a Troublesome Genius. Oxford: Oxford University Press.

Tesi, Valerio. 1991. Il Palazzo del Quirinale nel Cinquecento. In Il palazzo del Quirinale, ed. Franco Borsi, 77-114. Roma: Editoriale Lavoro.

Van Assche, Kristof. 1999. Louis Richeome, Ignatius, and Philostrates in the Novice's Garden: Or, the signification of Everyday Environment. In The Jesuits and the Emblem Tradition (Imago Figurata Studies 1a), eds. J. Manning and M. Van Vaeck, 3-10. Turnhout: Brepols. 
Van Berkel, Klaas. 2002. 'Cornelius Meijer inventor et fecit'. On the Representation of Science in Late Seventeenth Century Rome. In Merchants and Marvels. Commerce, Science and Art in Early Modern Europe, eds. P. H. Smith and P. Findlen, 277-294. New York: Routledge.

Van Damme, Stéphane. 2005. Le temple de la sagesse. Savoirs, écritures et sociabilité urbaine (Lyon, XVIIe-XVIIIe siècles). Paris: Éditions de l'EHESS.

Vermeir, Koen. 2007. Athanasius Kircher's Magical Instruments: An Essay on 'Science', 'Religion', and Applied Metaphysics. Studies in History and Philosophy of Science 38: 363-400.

Wind, Geraldine Dunphy. 2013. Sant'Andrea al Quirinale and the sundial. Source. Notes in the History of Art 32: 19-26.

Witte, Arnold. 2011. The Power of Repetition. Christian Doctrine and the Visual Exegesis of Nature in Sixteenth- and Seventeenth-century Painting. In Sacred Landscape. Landscape as Exegesis in Early Modern Europe, eds. Denis Ribouillault and Michel Weemans, 91-112. Florence: Olschki.

Zampa, Paola. 2007. 'Per comodità, diletto e sicurezza': il complesso del Quirinale nei progetti e nelle sistemazioni di Urbano VIII. In I Barberini e la cultura europea del Seicento, Atti del Convegno Internazionale, Roma, palazzo Barberini, 7-11 dicembre 2004, 501-512. Rome: De Luca. 